National Water-Quality Assessment Program

Source Water-Quality Assessment

Concentration Data for Anthropogenic Organic Compounds in Groundwater, Surface Water, and Finished Water of Selected Community Water Systems in the United States, 2002-10

Data Series 544 



\section{Concentration Data for Anthropogenic Organic Compounds in Groundwater, Surface Water, and Finished Water of Selected Community Water Systems in the United States, 2002-10}

By Janet M. Carter, James A. Kingsbury, Jessica A. Hopple, and Gregory C. Delzer

National Water-Quality Assessment Program Source Water-Quality Assessment

Data Series 544 


\section{U.S. Department of the Interior \\ KEN SALAZAR, Secretary \\ U.S. Geological Survey \\ Marcia K. McNutt, Director}

\section{U.S. Geological Survey, Reston, Virginia: 2010}

For more information on the USGS - the Federal source for science about the Earth, its natural and living resources, natural hazards, and the environment, visit http://www.usgs.gov or call 1-888-ASK-USGS

For an overview of USGS information products, including maps, imagery, and publications, visit http://www.usgs.gov/pubprod

Any use of trade, product, or firm names is for descriptive purposes only and does not imply endorsement by the U.S. Government.

Although this report is in the public domain, permission must be secured from the individual copyright owners to reproduce any copyrighted materials contained within this report.

Suggested citation:

Carter, J.M., Kingsbury, J.A., Hopple, J.A., and Delzer, G.C., Concentration data for anthropogenic organic compounds in groundwater, surface water, and finished water of selected community water systems in the United States, 2002-10: U.S. Geological Survey Data Series 544, 36 p. 


\section{FOREWORD}

The U.S. Geological Survey (USGS) is committed to providing the Nation with reliable scientific information that helps to enhance and protect the overall quality of life and that facilitates effective management of water, biological, energy, and mineral resources (http://www. usgs. gov/. Information on the Nation's water resources is critical to ensuring long-term availability of water that is safe for drinking and recreation and is suitable for industry, irrigation, and fish and wildlife. Population growth and increasing demands for water make the availability of that water, measured in terms of quantity and quality, even more essential to the long-term sustainability of our communities and ecosystems.

The USGS implemented the National Water-Quality Assessment (NAWOA) Program in 1991 to support national, regional, State, and local information needs and decisions related to water-quality management and policy (http://water.usgs.gov/nawqa). The NAWQA Program is designed to answer: What is the quality of our Nation's streams and groundwater? How are conditions changing over time? How do natural features and human activities affect the quality of streams and groundwater, and where are those effects most pronounced? By combining information on water chemistry, physical characteristics, stream habitat, and aquatic life, the NAWQA Program aims to provide science-based insights for current and emerging water issues and priorities. From 1991 to 2001, the NAWQA Program completed interdisciplinary assessments and established a baseline understanding of water-quality conditions in 51 of the Nation's river basins and aquifers, referred to as Study Units (http://water.usgs.gov/nawqa/studies/ study_units.html.

National and regional assessments are ongoing in the second decade (2001-2012) of the NAWQA Program as 42 of the 51 Study Units are selectively reassessed. These assessments extend the findings in the Study Units by determining water-quality status and trends at sites that have been consistently monitored for more than a decade, and filling critical gaps in characterizing the quality of surface water and groundwater. For example, increased emphasis has been placed on assessing the quality of source water and finished water associated with many of the Nation's largest community water systems. During the second decade, NAWOA is addressing five national priority topics that build an understanding of how natural features and human activities affect water quality, and establish links between sources of contaminants, the transport of those contaminants through the hydrologic system, and the potential effects of contaminants on humans and aquatic ecosystems. Included are studies on the fate of agricultural chemicals, effects of urbanization on stream ecosystems, bioaccumulation of mercury in stream ecosystems, effects of nutrient enrichment on aquatic ecosystems, and transport of contaminants to public-supply wells. In addition, national syntheses of information on pesticides, volatile organic compounds (VOCs), nutrients, trace elements, and aquatic ecology are continuing.

The USGS aims to disseminate credible, timely, and relevant science information to address practical and effective water-resource management and strategies that protect and restore water quality. We hope this NAWQA publication will provide you with insights and information to meet your needs, and will foster increased citizen awareness and involvement in the protection and restoration of our Nation's waters.

The USGS recognizes that a national assessment by a single program cannot address all waterresource issues of interest. External coordination at all levels is critical for cost-effective management, regulation, and conservation of our Nation's water resources. The NAWQA Program, 
therefore, depends on advice and information from other agencies-Federal, State, regional, interstate, Tribal, and local—as well as nongovernmental organizations, industry, academia, and other stakeholder groups. Your assistance and suggestions are greatly appreciated.

William H. Werkheiser

USGS Associate Director for Water 


\section{Contents}

Abstract

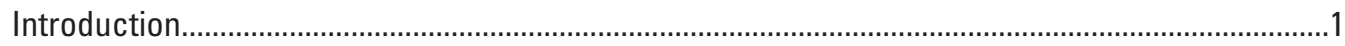

Purpose and scope

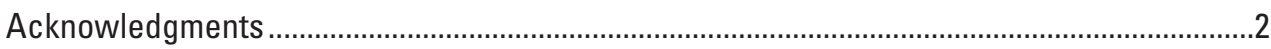

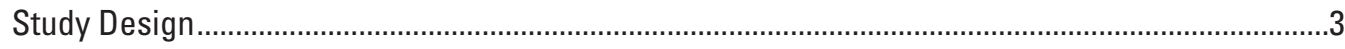

Selection of Groundwater Sites .........................................................................................

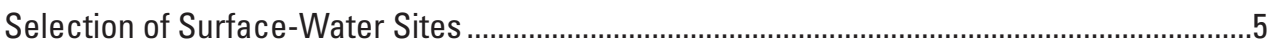

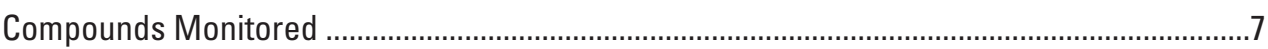

Sample Collection and Analytical Methods ………..............................................................

Quality Assurance ...............................................................................................................

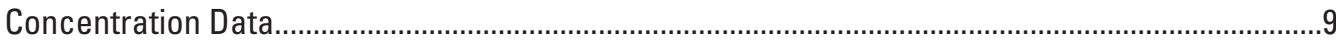

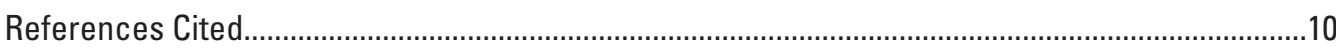

Appendix 1. Compounds analyzed in Source Water-Quality Assessment studies by primary use or source groups.

Appendix 2. Concentrations of anthropogenic organic compounds in groundwater and associated finished water from community water systems and in quality-assurance samples for Source Water-Quality Assessment studies, 2002-10

Appendix 3. Concentrations of anthropogenic organic compounds in surface water and associated finished water from community water systems and in quality-assurance samples for Source Water-Quality Assessment studies, 2002-10.

\section{Figure}

1. Map showing location of Source Water-Quality Assessment studies for which samples were collected during 2002-10...

\section{Tables}

1. Description of sampling components for Source Water-Quality Assessment studies during 2002-10.

2. Principal aquifers or aquifer systems sampled for groundwater Source WaterQuality Assessment studies during 2002-10.

3. Rivers sampled for surface-water Source Water-Quality Assessment studies during 2002-10.

4. Primary use or source groups for compounds analyzed for groundwater and surface-water Source Water-Quality Assessment studies, 2002-10. 


\section{Conversion Factors}

\begin{tabular}{ccc} 
SI to Inch/Pound & & \\
\hline Multiply & By & To obtain \\
\hline & Length & \\
\hline kilometer $(\mathrm{km})$ & 0.6214 & mile (mi)
\end{tabular}

Horizontal coordinate information is referenced to the North American Datum of 1983 (NAD $83)$.

Concentrations of chemical constituents in water are given either in milligrams per liter $(\mathrm{mg} / \mathrm{L})$ or micrograms per liter $(\mu \mathrm{g} / \mathrm{L})$.

\section{Acronyms and Abbreviations}

$\begin{array}{ll}< & \text { less than } \\ \text { AOC } & \text { anthropogenic organic compound } \\ \text { BTEX } & \text { benzene, toluene, ethylbenzene, and xylenes } \\ \text { CWS } & \text { community water system } \\ \text { DEET } & \text { N,N-diethyl-meta-toluamide } \\ \text { E } & \text { estimated } \\ \text { GC/MS } & \text { gas chromatography-mass spectrometry } \\ \text { HPLC/MS } & \text { high performance liquid chromatography-mass spectrometry } \\ \text { LRL } & \text { laboratory reporting level } \\ \text { LT-MDL } & \text { long-term method detection level } \\ \text { NAWQA } & \text { National Water-Quality Assessment } \\ \text { NWQL } & \text { National Water Quality Laboratory } \\ \text { R } & \text { removed } \\ \text { SWQA } & \text { Source Water-Quality Assessment } \\ \text { USGS } & \text { U.S. Geological Survey } \\ \text { VOC } & \text { volatile organic compound }\end{array}$




\title{
Concentration Data for Anthropogenic Organic Compounds in Groundwater, Surface Water, and Finished Water of Selected Community Water Systems in the United States, 2002-10
}

\author{
By Janet M. Carter, James A. Kingsbury, Jessica A. Hopple, and Gregory C. Delzer
}

\section{Abstract}

The National Water-Quality Assessment Program of the U.S. Geological Survey began implementing Source Water-Quality Assessments (SWQAs) in 2001 that focus on characterizing the quality of source water and finished water of aquifers and major rivers used by some of the larger community water systems in the United States. As used in SWQA studies, source water is the raw (ambient) water collected at the supply well before water treatment (for groundwater) or the raw (ambient) water collected from the river near the intake (for surface water), and finished water is the water that has been treated and is ready to be delivered to consumers. Finished-water samples are collected before the water enters the distribution system.

The primary objective of SWQAs is to determine the occurrence of more than 250 anthropogenic organic compounds in source water used by community water systems, many of which currently are unregulated in drinking water by the U.S. Environmental Protection Agency. A secondary objective is to understand recurrence patterns in source water and determine if these patterns also occur in finished water before distribution. SWQA studies were conducted in two phases for most studies completed by 2005, and in one phase for most studies completed since 2005.

Analytical results are reported for a total of 295 different anthropogenic organic compounds monitored in source-water and finished-water samples collected during 2002-10. The 295 compounds were classified according to the following 13 primary use or source groups: (1) disinfection by-products; (2) fumigant-related compounds; (3) fungicides; (4) gasoline hydrocarbons, oxygenates, and oxygenate degradates; (5) herbicides and herbicide degradates; (6) insecticides and insecticide degradates; (7) manufacturing additives; (8) organic synthesis compounds; (9) pavement- and combustion-derived compounds; (10) personal-care and domestic-use products;
(11) plant- or animal-derived biochemicals; (12) refrigerants and propellants; and (13) solvents.

This report presents the analytical results of sourcewater samples from 448 community water system wells and 21 surface-water sites. This report also presents the analytical results of finished-water samples from 285 wells and 20 surface-water sites from community water systems. Results of quality-assurance/quality-control samples also are presented including data for equipment blanks, field blanks, source solution blanks, and replicate samples.

\section{Introduction}

In 1991, the U.S. Geological Survey (USGS) began the National Water-Quality Assessment (NAWQA) Program to (1) provide a nationally consistent description of current water-quality conditions for the 51 largest and most important aquifers and river basins across the Nation; (2) define longterm trends in water quality; and (3) identify, describe, and explain, as possible, the primary factors that affect observed water-quality conditions and trends (Gilliom and others, 1995). This information, which is obtained on a continuing basis, is made available to water managers, policy makers, and the general public to provide an improved scientific basis for evaluating the effectiveness of water-quality management programs and for predicting the likely effects of contemplated changes in land- and water-management practices. The first decade of the NAWQA Program focused on describing current water-quality conditions.

Beginning in 2001, the NAWQA Program began its second decade of intensive assessment activities, returning to 42 (14 each in 2001, 2004, and 2007, respectively) of the 51 original aquifers and river basins studied, termed Study Units. In addition to providing a description of current waterquality conditions, these studies place increased emphasis on 
the latter two goals of the Program-trends and understanding. In addition, a new assessment activity during the second decade of NAWQA is Source Water-Quality Assessments (SWQAs) that focus on characterizing the quality of source water and finished water of aquifers and major rivers used by some of the larger community water systems (CWSs) in the United States. As used in this study, source water is the raw (ambient) water collected at the supply well before water treatment (for groundwater) or the raw (ambient) water collected from the river near the intake (for surface water), and finished water is the water that has been treated and is ready to be delivered to consumers. Finished-water samples are collected before the water enters the distribution system. Finished water from groundwater supplies may have been blended with water from several groundwater sources, but was not blended with water from any surface-water sources. Finished water from surface-water supplies typically was not blended with any additional surface-water or groundwater sources.

SWQA studies are intended to complement drinkingwater monitoring required by Federal, State, and local programs, which focus primarily on post-treatment compliance monitoring. Through SWQA studies, NAWQA is increasing its emphasis on characterizing the water quality of rivers and aquifers that are primary sources of drinking water and will allow results from other NAWQA sites to be put into context with the source of water used for water supply. Additionally, the quality of source water for a large number of compounds not regulated in drinking water by the U.S. Environmental Protection Agency also will be determined. Through SWQA studies, the USGS will continue to collaborate with other agencies and organizations involved with supplying and managing drinking water. To help accomplish this, USGS staff maintains a close working relationship with CWS personnel that are utilizing the source waters investigated.

The primary objective of SWQAs is to determine the occurrence of more than 250 primarily unregulated anthropogenic organic compounds in source water used by community water systems (Delzer and Hamilton, 2007). A secondary objective is to understand recurrence patterns in source water and determine if these patterns also occur in finished water before distribution. SWQA studies were conducted in two phases for most studies completed by 2005, and in one phase for most studies completed since 2005. The objectives of SWQA studies were met by collecting groundwater (source), surface-water (source), and finished-water samples, and analyzing these samples for anthropogenic organic compounds (AOCs).

The AOC data for the SWQAs completed during 2002-05 were presented in Carter and others (2007) and included data for the first 15 groundwater and 9 surface-water SWQAs that were sampled. Findings for the groundwater SWQAs completed during 2002-05 were presented in Hopple and others (2009), and findings for the surface-water SWQAs were presented in Kingsbury and others (2008a, 2008b). This update to Carter and others (2007) includes data for 15 additional groundwater SWQAs and 11 additional surface-water SWQAs that were completed during 2006-10. Thus, this report includes data for 30 groundwater and 20 surface-water SWQAs that were completed during 2002-10 and includes data presented in Carter and others (2007).

Before June 2005, source-water samples were analyzed for 258 AOCs. During and after June 2005, the source-water samples were analyzed for $275 \mathrm{AOCs}$, which includes all but one (fonofos, oxygen analog) of the same AOCs monitored before June 2005, plus 18 additional compounds that were not monitored previously for the SWQA studies. For SWQA studies conducted during 2002-10, samples from a subset of wells and surface-water sites also were analyzed for 3 additional pesticides and 16 pesticide degradates. Thus, sourcewater samples were analyzed for a total of 277 compounds before June 2005 and for a total of 294 compounds during and after June 2005. However, the total number of different AOCs analyzed for Source Water-Quality Assessment studies during 2002-10 was 295 because of the discontinuation of analyses of fonofos, oxygen analog, during June 2005.

\section{Purpose and scope}

The purpose of this report is to present concentration data for AOCs in groundwater, surface water, and finished water of CWSs sampled for SWQA studies during 2002-10. No interpretations of the concentration data are included in this report. Analytical results are reported for a total of 295 different AOCs. Specifically, this report presents the analytical results of source-water samples from $448 \mathrm{CWS}$ wells and 21 surfacewater sites. This report also presents the analytical results of finished-water samples from 285 wells and 20 surface-water sites from CWSs.

Results of quality-assurance/quality-control samples collected for SWQA studies during 2002-10 also are presented including data from equipment blanks, field blanks, source solution blanks, and replicate samples. Matrix spike data collected through 2006 are presented in Valder and others (2008). Data from all source-water, finished-water, and quality-control samples collected by each SWQA were reviewed to evaluate potential bias (primarily systematic contamination) associated with sample collection, processing, transportation, and analysis. If quality-control data indicated that results for environmental data were biased as a result of systematic contamination, environmental data were removed from the dataset presented in this report.

\section{Acknowledgments}

The authors thank the many CWS personnel who helped coordinate sample collection and provided permission to sample. Study Unit personnel are thanked for collecting the samples. Jack Barbash, David Bender, and Dana Kolpin are thanked for their help in compiling information for the primary use or source groups for the AOCs monitored as part of the SWQA studies. 


\section{Study Design}

This section of the report describes the criteria used for selection of sampling sites for the SWQA studies. In addition, sample collection, analytical methods, and quality-assurance activities used to characterize the quality of compounds monitored are described.

Three different sampling components were used for the groundwater and surface-water SWQA studies conducted during 2002-10 (table 1). Sampling component 1 was used as the initial sampling phase for most studies conducted during 2002-05. For sampling component 1 , source-water samples were collected and analyzed for all AOCs. Sampling component 2 was used as the second sampling phase for most of the studies conducted during 2002-05. During this second sampling phase, samples were collected from a subset of the wells sampled during the initial sampling phase and analyzed for those AOCs found to occur most frequently or at relatively higher concentrations during the initial sampling phase. Sampling component 3 was used for most SWQA studies conducted after 2005. For sampling component 3, source-water and finished-water samples were collected and analyzed for all AOCs. For sampling components 2 and 3, the finished-water samples were collected within a few hours or as much as 2 days after the source-water samples to account for residence time at the treatment plant.

Table 1. Description of sampling components for Source Water-Quality Assessment studies during 2002-10.

\begin{tabular}{|c|c|c|}
\hline $\begin{array}{l}\text { Sampling } \\
\text { component }\end{array}$ & Description & $\begin{array}{c}\text { Approximate } \\
\text { sampling dates }\end{array}$ \\
\hline 1 & $\begin{array}{l}\text { Only source-water samples col- } \\
\text { lected; analyzed for all anthro- } \\
\text { pogenic organic compounds }\end{array}$ & $2002-05$ \\
\hline 2 & $\begin{array}{l}\text { Source-water and finished- } \\
\text { water samples collected from } \\
\text { a subset of sites monitored } \\
\text { during sampling component } \\
\text { 1; analyzed for those anthro- } \\
\text { pogenic organic compounds } \\
\text { found to occur most frequently } \\
\text { or at relatively higher con- } \\
\text { centrations during sampling } \\
\text { component } 1\end{array}$ & $2002-05$ \\
\hline 3 & $\begin{array}{l}\text { Source-water and finished-water } \\
\text { samples collected; analyzed for } \\
\text { all anthropogenic compounds }\end{array}$ & $2006-10$ \\
\hline
\end{tabular}

Source-water data collected using sampling components 1 and 3 can be used to characterize the occurrence of AOCs in source water to meet the primary objective of SWQA studies. Source-water data collected using sampling component 2 would not be used to characterize the occurrence of AOCs in source water because these samples were collected at sites where AOCs were found to occur during sampling component 1 and were analyzed for AOCs that occurred frequently or at relatively higher concentrations during sampling component 1 , and thus are not representative of general occurrence. Source-water and finished-water samples collected during sampling components 2 and 3 can be used to meet the secondary objective of SWQA studies, which is to understand recurrence patterns of AOCs in source water and determine if these patterns also occur in finished water before distribution.

\section{Selection of Groundwater Sites}

A total of 30 groundwater SWQAs were conducted and completed (fig. 1) and the source water from a total of 448 wells were sampled during 2002-10 (table 2). A total of 285 finished-water samples were collected during 2002-10.

Sixteen SWQAs were completed using two sampling phases (components 1 and 2), which were used for most SWQA studies conducted during 2002-05. These 16 SWQAs represent 14 NAWQA Study Units. Two of these Study Units - Georgia-Florida Coastal Plain (GAFL; map numbers 6 and 7 on figure 1) and Upper Mississippi River Basin (UMIS; map numbers 27 and 28 on figure 1) - had two SWQA studies (table 2). For one of these 16 SWQA studies (South Platte River Basin), source-water and finished-water samples were not collected during the second phase because AOCs were detected infrequently and at relatively low concentrations in source water during the initial sampling phase. For each groundwater SWQA, about 15 CWS wells were selected, for a total of 237 wells sampled for source water using a two-phase approach. Source water and finished water were monitored as part of sampling component 2 for about 85 of the $237 \mathrm{CWS}$ wells.

Fourteen SWQAs were completed using a single sampling phase (component 3), which was used for most SWQA studies conducted after 2005. These 14 SWQAs represent 13 NAWQA Study Units. One of these Study Units-Southern Florida (SOFL; map numbers 23 and 24 on figure 1) - had two SWQA studies (table 2). A total of 211 wells were sampled for source and finished water through 2010 using a single sampling phase.

The selection process for CWS wells considered several criteria. The wells selected withdraw water from a principal aquifer or system (table 2), and groundwater represents a substantial portion of drinking water in the area. Additionally, groundwater used by the selected CWSs potentially was vulnerable to anthropogenic contamination because of large groundwater withdrawal rates from the aquifer and the proximity of wells to urban areas. Finally, the wells sampled fit into a national network of wells that collectively cover a variety of environmental land-use settings such as agriculture, urban, and mixed.

Within an SWQA study area, the highest producing wells typically were selected for sampling because these wells have the largest contributing areas, which may increase the potential for contamination. Annual production data obtained from 
Table 2. Principal aquifers or aquifer systems sampled for groundwater Source Water-Quality Assessment studies during 2002-10.

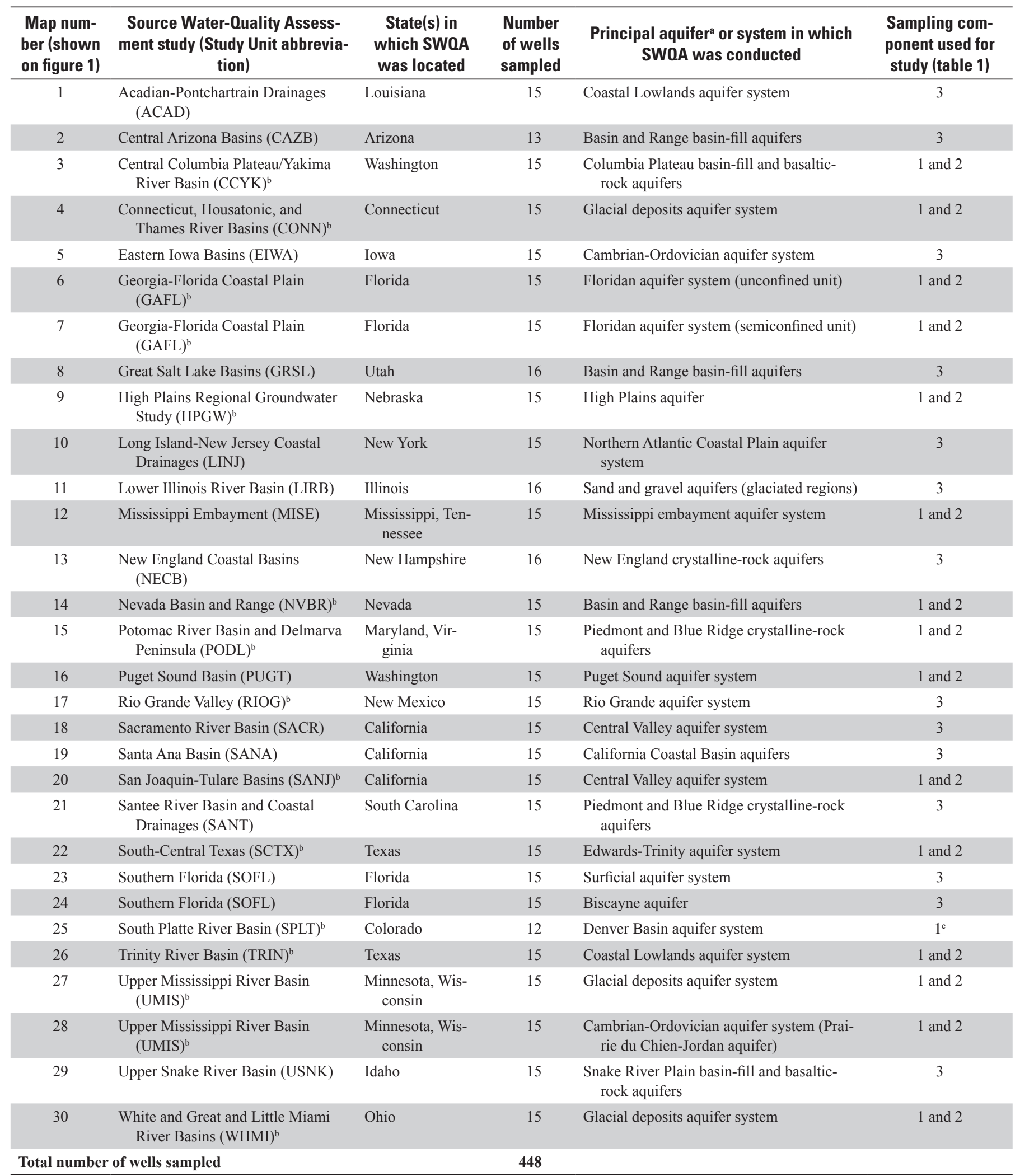

aPrincipal aquifer from U.S. Geological Survey (2003).

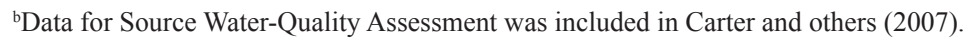

${ }^{\mathrm{c}}$ No source-water or finished-water samples from this site were collected during sampling component 2. 
the CWSs were used to characterize withdrawals for the CWS wells. In some cases, annual production data for individual wells were not available, so production volume for a well field or pumping center was used. The top quartile of individual CWS wells or pumping centers in a study area was characterized, and 15 CWS wells randomly were selected from those in the top quartile. For areas where the top quartile did not contain enough wells or pumping centers for a random selection of 15 wells to occur, a larger group of wells (for example, the upper one-half) was used. Wells sampled were at least 1 kilometer $(\mathrm{km})$ apart to ensure that the contributing areas for wells did not overlap and to be consistent with other NAWQA studies (for example, Toccalino and others, 2010). The type of water treatment used by the CWSs was not considered in the selection process.

In certain aquifer systems, some of the highest-producing CWS wells were located near surface-water bodies, which could result in induced infiltration of surface water to the wells. CWS wells with strong connections to streams (under the influence of surface water) were not used. Similarly, CWS wells in coastal or bay areas with induced infiltration from seawater, and wells used for injection and subsequent withdrawal of artificial recharge also were excluded because water from these types of wells does not represent recharge from the land surface.

\section{Selection of Surface-Water Sites}

A total of 20 surface-water SWQAs were conducted during 2002-10 (table 3, fig. 1), with a total of 21 source-water sites sampled and 20 finished-water sites sampled. Water quality from surface-water SWQAs was monitored in 12 NAWQA Study Units as part of sampling component 1 and in 8 Study Units as part of sampling component 3 (table 3 ). For most surface-water SWQAs conducted during 2002-05, one site was selected for each SWQA and sampled monthly for about 1 year as part of sampling component 1 . During the second sampling phase (sampling component 2), source water and finished water were sampled for 11 of the 12 surface-water SWQAs monitored using sampling component 1 ; finishedwater samples were not collected from the South Platte River Basin Study Unit during this second phase because relatively few AOCs were detected during the initial sampling phase for this SWQA. For most SWQAs conducted after 2005, sourcewater and finished-water samples were collected for eight

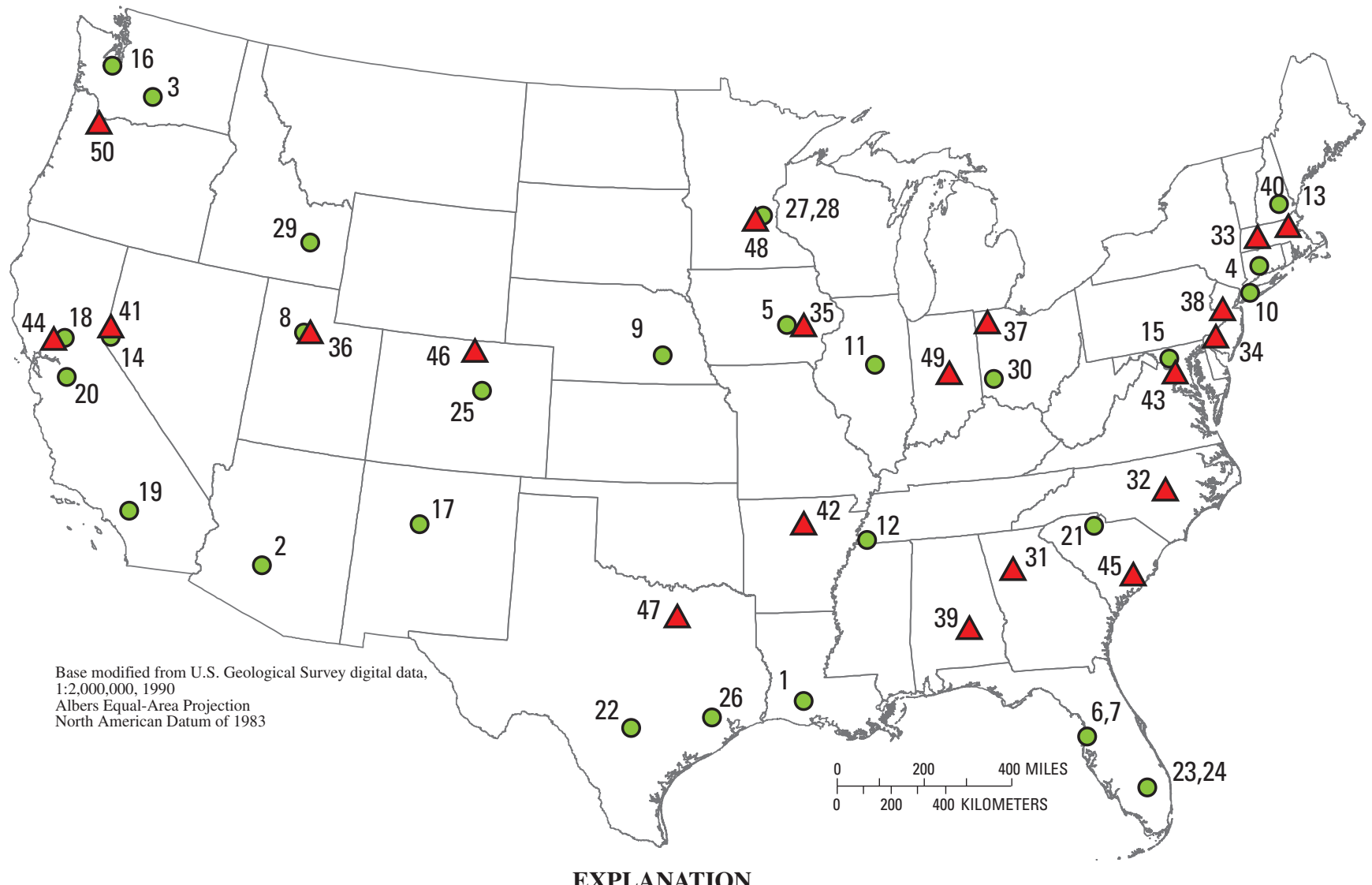

10 Groundwater-Number is map number in table 2

$31 \triangle$ Surface water-Number is map number in table 3

Figure 1. Location of Source Water-Quality Assessment studies for which samples were collected during 2002-10. 
Table 3.. $\quad$ Rivers sampled for surface-water Source Water-Quality Assessment studies during 2002-10.

\begin{tabular}{|c|c|c|c|c|}
\hline $\begin{array}{l}\text { Map number } \\
\text { (shown on } \\
\text { figure 1) }\end{array}$ & $\begin{array}{l}\text { Source Water-Quality Assessment study } \\
\text { (Study unit abbreviation) }\end{array}$ & River & $\begin{array}{l}\text { System } \\
\text { size }^{\mathrm{a}}\end{array}$ & $\begin{array}{l}\text { Sampling component } \\
\text { used for study } \\
\text { (table 1) }\end{array}$ \\
\hline 31 & $\begin{array}{l}\text { Apalachicola-Chattahoochee-Flint River } \\
\text { Basins }(\mathrm{ACFB})^{\mathrm{b}}\end{array}$ & Chattahoochee River, Georgia & Very large & 1 and 2 \\
\hline 32 & Albemarle-Pamlico Drainage Basin (ALBE) ${ }^{b}$ & Neuse River, North Carolina & Large & 1 and 2 \\
\hline 33 & $\begin{array}{l}\text { Connecticut, Housatonic, and Thames River } \\
\text { Basins }(\mathrm{CONN})^{\mathrm{b}}\end{array}$ & Running Gutter Creek, Massachusetts & Small & 1 and 2 \\
\hline 34 & Delaware River Basin (DELR) & Schuylkill River, Pennsylvania & Very large & 3 \\
\hline 35 & Eastern Iowa Basins (EIWA) & Iowa River, Iowa & Large & 3 \\
\hline 36 & Great Salt Lake Basins (GRSL) & Provo River, Utah & Very large & 3 \\
\hline 37 & Lake Erie-Lake Saint Clair Drainages (LERI) & Maumee River, Ohio & Large & 3 \\
\hline 38 & $\begin{array}{l}\text { Long Island-New Jersey Coastal Drainages } \\
\text { (LINJ) }\end{array}$ & Raritan River, New Jersey & Very large & 3 \\
\hline 41 & Nevada Basin and Range (NVBR) ${ }^{\mathrm{b}}$ & Truckee River, Nevada & Very large & 1 and 2 \\
\hline 42 & Ozark Plateaus (OZRK) & White River, Arkansas & Large & 3 \\
\hline 43 & $\begin{array}{l}\text { Potomac River Basin and Delmarva Penin- } \\
\text { sula (PODL) }\end{array}$ & Potomac River, Maryland & Very large & 1 and 2 \\
\hline 44 & Sacramento River Basin (SACR) & Sacramento River, California & Large & 1 and 2 \\
\hline 45 & $\begin{array}{l}\text { Santee River Basin and Coastal Drainages } \\
\text { (SANT) }\end{array}$ & Back River, South Carolina & Very large & 1 and 2 \\
\hline 46 & South Platte River Basin (SPLT) ${ }^{b}$ & Cache la Poudre River, Colorado & Very large & $1^{\mathrm{c}}$ \\
\hline 47 & Trinity River Basin (TRIN) ${ }^{\mathrm{b}}$ & Elm Fork Trinity River, Texas & Very large & 1 and 2 \\
\hline
\end{tabular}

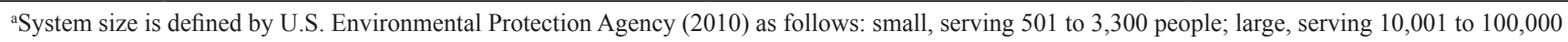
people; and very large, serving more than 100,000 people.

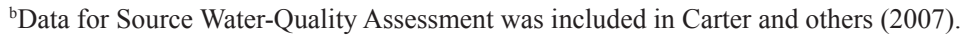

${ }^{\mathrm{c}}$ No source-water or finished-water samples from this site were collected during phase 2.

NAWQA Study Units as part of sampling component 3 (table 3). Similar to sampling component 1, one site was selected for each SWQA and sampled monthly for about 1 year using sampling component 3; however, for one SWQA (Long Island-New Jersey Coastal Drainages; map number 38 on figure 1), two different source-water sites and two different finished-water sites were sampled.

Several criteria were used in selecting a surface-water CWS site for SWQA monitoring. Source-water sites were selected on free-flowing stream reaches rather than on reservoirs to remain consistent with and to be able to compare results with other surface-water sites sampled by the NAWQA Program. In some cases, reservoirs were upstream from the surface-water CWS sites, but the closest reservoir was about $7 \mathrm{~km}$ upstream from the CWS intake. The median distance between the CWS intake and an upstream reservoir was about $40 \mathrm{~km}$, and the farthest reservoir was more than $100 \mathrm{~km}$ upstream from the intake. Additionally, CWSs selected for this study were single-source systems, with little or no blending of other source waters. Land use in the watershed and the type of water treatment used by the CWSs were not considerations in site selection.

The surface-water CWSs sampled represent a range in size (table 3) and are fairly well distributed across the United States (fig. 1). Nineteen of the $20 \mathrm{CWSs}$ are categorized as large or very large water systems, meaning that they provide water to more than 10,001 and 100,001 people, respectively (U.S. Environmental Protection Agency, 2010). One site, Running Gutter Creek, Massachusetts (map number 33 on figure 1), is a small CWS that serves fewer than 3,300 people. 


\section{Compounds Monitored}

The 295 AOCs monitored for SWQA studies during 2002-10 were categorized into the following 13 compound groups based on their primary use or source (table 4):

(1) disinfection by-products; (2) fumigant-related compounds; (3) fungicides and fungicide degradates; (4) gasoline hydrocarbons, oxygenates, and oxygenate degradates; (5) herbicides and herbicide degradates; (6) insecticides and insecticide degradates; (7) manufacturing additives; (8) organic synthesis compounds; (9) pavement- and combustion-derived compounds; (10) personal-care and domestic-use products; (11) plant- or animal-derived biochemicals; (12) refrigerants and propellants; and (13) solvents. Use information for the compounds analyzed for SWQA studies is presented in Appendix 1 .

\section{Sample Collection and Analytical Methods}

Groundwater, surface-water, and quality-control samples were collected using established USGS protocols (Koterba and others, 1995; U.S. Geological Survey, variously dated). Groundwater samples were collected at the wellhead before any treatment such as chlorination. Surface-water samples were collected approximately monthly with additional samples collected during selected flow conditions when water quality could change quickly or when concentrations or the number of compounds expected to occur were maximized. These samples were collected at a single depth integrated point as close as practical to the drinking-water intake and processed following standard USGS sampling protocols (U.S. Geological Survey, variously dated).

Finished-water samples associated with each groundwater and surface-water source-water sample were collected following all of the treatment steps before the water entered the water treatment plants' distribution systems. These samples typically were collected where samples are collected for compliance monitoring. The finished-water samples were collected within a few hours or as much as 2 days after the source-water samples to try to account for the residence time in the treatment plant based on information provided by treatment plant personnel. Finished-water samples typically contain free chlorine, which has been documented to degrade certain organic compounds that may be present in the water samples (Munch, 1995); therefore, a dechlorination reagent (ascorbic acid) and, for certain samples, $\mathrm{pH}$ buffers (Trizma) were added to finished-water samples during sample collection to stabilize them before analyses. The effect of these dechlorination reagents on the laboratory analysis was evaluated, and results indicated that analytical methodologies were not affected by the addition of these reagents (Mark Sandstrom, U.S. Geological Survey National Water Quality Laboratory, written commun., 2007). Finished-water sample results are not necessarily representative of drinking-water quality at the tap because samples were collected before distribution and thus do not account for the additional contact time that the water has with disinfectants in the distribution system.

Samples were analyzed using six USGS approved analytical schedules at the USGS National Water Quality Laboratory (NWQL) in Denver, Colorado, and described by Zaugg and others (1995), Lindley and others (1996), Connor and others (1998), Furlong and others (2001), Sandstrom and others (2001), Zaugg and others (2002), and Madsen and others (2003). These methods include gas chromatographymass spectrometry (GC/MS) and high performance liquid chromatography-mass spectrometry (HPLC/MS) analytical techniques. Samples collected for volatile organic compound (VOC) analyses using schedules 2020 and 4024 (Appendix 1) were chilled upon collection. Samples collected for analyses using schedule 2020 also were preserved using 1:1 hydrochloric acid. VOC sample sets were analyzed by purge and trap GC/MS (Connor and others, 1998; Rose and Sandstrom, 2003). Samples for analyses of pesticides and other semi-volatile compounds were filtered in the field through a 0.7 -micron baked glass fiber filter and chilled. These samples were extracted at the NWQL on solid-phase extraction cartridges to concentrate the analytes from the filtered samples. The solid-phase extraction cartridges were then eluted with a solvent and the extracts were analyzed by either GC/MS or HPLC/MS methods (Zaugg and others, 1995; Lindley and others, 1996; Furlong and others, 2001; Sandstrom and others, 2001; Zaugg and others, 2002; Madsen and others, 2003). During June 2005, schedule 2003 was replaced by schedule 2033, which includes all but one (fonofos, oxygen analog) of the same pesticides (fungicides, herbicides, and insecticides) monitored before June 2005, plus 18 additional compounds that were not monitored previously for the SWQA studies (Appendix 1). At a subset of sites, an additional sample was collected for the analysis of 3 herbicides and 16 herbicide degradates. These additional samples were analyzed using HPLC/MS by the Organic Geochemistry Research Group Laboratory, in Lawrence, Kansas (Lee and Strahan, 2003).

AOC concentrations detected below the lowest daily standard, or for information-rich methods, concentrations detected below the long-term method detection level (LTMDL), are reported as estimated concentrations (Childress and others, 1999). The laboratory report level (LRL) generally is equal to twice the yearly determined LT-MDL (Childress and others, 1999). The LT-MDL is a detection level derived by determining the standard deviation or a minimum of 24 MDL spike-sample measurements throughout an extended time. The LT-MDL data are collected on a continuous basis to assess year-to-year variations in the LT-MDL. The chance of falsely reporting a concentration at or greater than the LTMDL for a sample that did not contain the analyte is predicted to be less than or equal to 1 percent (Childress and others, 1999). Also, at low concentrations, especially concentrations less than the LRL, the variability of detection is high, false negatives are more likely, and greater variability in reported concentrations is expected (Martin, 2002). Concentrations greater than the LRL sometimes are reported as estimated 
Table 4. Primary use or source groups for compounds analyzed for groundwater and surface-water Source Water-Quality Assessment studies, 2002-10.

[BTEX: benzene, toluene, ethylbenzene, and xylenes]

\begin{tabular}{|c|c|c|c|}
\hline \multirow{2}{*}{$\begin{array}{l}\text { Primary use or } \\
\text { source group }\end{array}$} & \multirow{2}{*}{ Description } & \multicolumn{2}{|c|}{$\begin{array}{l}\text { Number of compounds } \\
\text { in group for samples } \\
\text { analyzed }\end{array}$} \\
\hline & & $\begin{array}{l}\text { Before } \\
\text { June } \\
2005\end{array}$ & $\begin{array}{l}\text { During and } \\
\text { after June } \\
2005\end{array}$ \\
\hline $\begin{array}{l}\text { Disinfection by- } \\
\text { products }\end{array}$ & $\begin{array}{l}\text { Trihalomethanes, (poly)haloacetic acids and other compounds that are produced from the trans- } \\
\text { formation of organic compounds during the disinfection of water and wastewater through } \\
\text { chlorination, ozonation, or other chemical methods. }\end{array}$ & 4 & 4 \\
\hline $\begin{array}{l}\text { Fumigant-related } \\
\text { compounds }\end{array}$ & $\begin{array}{l}\text { Chemicals that may be present in commercial fumigant products, which produce a gas, vapor, } \\
\text { fumes, or smoke intended to destroy, repel, or control unwanted organisms such as insects, } \\
\text { bacteria, or rodents. These include fumigant active ingredients, as well as their degradates } \\
\text { and their manufacturing by-products. }\end{array}$ & 9 & 9 \\
\hline $\begin{array}{l}\text { Fungicides and } \\
\text { fungicide deg- } \\
\text { radates }\end{array}$ & Pesticides that are used to kill unwanted fungi. & 7 & 11 \\
\hline $\begin{array}{l}\text { Herbicides and } \\
\text { herbicide degra- } \\
\text { dates }\end{array}$ & $\begin{array}{l}\text { Pesticides designed to kill unwanted plants (herbicides) and compounds produced from the } \\
\text { transformation of the parent herbicide following application (degradates). }\end{array}$ & 82 & 88 \\
\hline $\begin{array}{l}\text { Insecticides and } \\
\text { insecticide } \\
\text { degradates }\end{array}$ & $\begin{array}{l}\text { Pesticides designed to kill unwanted insects (insecticides) and compounds produced from the } \\
\text { transformation of the parent insecticide following application (degradates). }\end{array}$ & 51 & 58 \\
\hline $\begin{array}{l}\text { Personal-care and } \\
\text { domestic-use } \\
\text { products }\end{array}$ & $\begin{array}{l}\text { Compounds that are present in commercial products sold for personal or residential use, such } \\
\text { as fragrances, pharmaceuticals, insect repellants, dyes, detergents, disinfectants, shampoos, } \\
\text { and chemicals used in fire extinguishers. }\end{array}$ & 26 & 26 \\
\hline $\begin{array}{l}\text { Plant- or animal- } \\
\text { derived bio- } \\
\text { chemicals }\end{array}$ & $\begin{array}{l}\text { Naturally occurring compounds that are produced by plants or animals, either through direct } \\
\text { biosynthesis or through the metabolic alteration of compounds ingested or taken up from } \\
\text { other sources. These compounds are predominantly unsaturated solid alcohols of the steroid } \\
\text { group naturally occurring in fatty tissues of plants and animals and present in animal fecal } \\
\text { material. }\end{array}$ & 5 & 5 \\
\hline $\begin{array}{l}\text { Refrigerants and } \\
\text { propellants }\end{array}$ & $\begin{array}{l}\text { Volatile compounds that are used for commercial or domestic refrigeration, as blowing agents } \\
\text { in the manufacture of packaging and other highly porous materials, or for dispensing other } \\
\text { substances from spray cans and other aerosol delivery devices. }\end{array}$ & 3 & 3 \\
\hline Solvents & $\begin{array}{l}\text { Compounds that are used to dissolve other substances. Two of the more common solvents are } \\
\text { trichloroethene (TCE) and perchloroethene (PCE). }\end{array}$ & 33 & 33 \\
\hline \multicolumn{2}{|c|}{ Total number of compounds ${ }^{a}$} & 277 & 294 \\
\hline
\end{tabular}

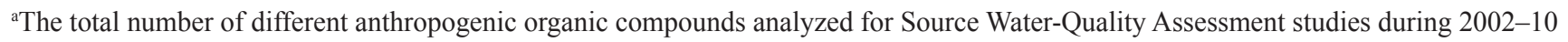
was 295. 
concentrations for some AOCs because of the variability in the analytical method, poor recovery, or by loss processes such as water-matrix interferences that result in false-negative errors. Concentrations are censored and reported as less than $(<)$ the LRL when the compound was not detected.

\section{Quality Assurance}

Quality-assurance/quality-control samples collected for SWQA studies include equipment blanks, field blanks, source solution blanks, and replicate samples. The various blank samples consisted of nitrogen-purged organic-free blank water. Equipment blanks typically are collected in a laboratory setting using the same sampling equipment used to collect environmental samples and typically are collected before the environmental samples are collected. Equipment blanks are used to evaluate the cleanliness of sampling equipment. Field blanks are collected near sampling sites and are processed in the field in the same manner as environmental samples. Field blanks are used to evaluate potential sample contamination from sampling equipment, cleaning procedures, and the atmosphere. Source solution blanks are used to determine the presence or absence of compounds in the water used to clean equipment and process field blanks. The various blank samples also provide information on contamination during shipment. Replicate samples measure the combined precision of sampling and laboratory analyses. Matrix spike samples, which provide information about recoveries of organic compounds, also were collected for SWQA studies and were reported for 2004 to 2006 by Valder and others (2008).

Data from all source-water, finished-water, and qualitycontrol samples collected by each SWQA were reviewed to evaluate potential bias (primarily systematic contamination) associated with sample collection, processing, transportation, and analysis. A review of the quality-control data along with the associated environmental data is important because the relatively small number of samples collected in each study area generally is not adequate to characterize the full magnitude of potential bias on an individual SWQA basis. A larger dataset that covers the entire period of sample collection for SWQA studies provides greater insight to possible systematic errors that bias sample results. These quality-control reviews were completed on an annual basis. If quality-control data indicated that results for environmental data were biased as a result of systematic contamination, environmental data were removed from the dataset presented in this report by coding concentrations with an "R."

Data for seven AOCs were removed from the dataset presented in this report because of systematic contamination or analytical variability. Phenol was detected frequently in field and laboratory blanks and at concentrations comparable to concentrations measured in environmental samples; thus, concentrations for phenol were removed for this report by coding concentrations with an "R." Studies conducted by the NWQL (Mark Sandstrom, USGS National Water Quality Laboratory, oral commun., 2005) indicated that samples can be contaminated if N,N-diethyl-meta-toluamide (DEET) is used by sampling personnel. The frequent detection of DEET in field blanks caused uncertainty in the quality of DEET concentrations in environmental samples; thus, concentrations for DEET were removed for this report by coding concentrations with an "R." Three compounds - benzophenone, isophorone, and para-nonylphenol - were detected frequently in field blanks because of the presence of these compounds in the $\mathrm{pH}$ buffer (Trizma) obtained from the vendor. Because the quality of data for benzophenone, isophorone, and para-nonylphenol is not fully understood, concentrations for these three compounds also were removed for this report by coding concentrations with an "R." Laboratory analyses of bisphenol A and pentachlorophenol produced unreliable data starting in March 2005 (Dave Reppert, USGS National Water Quality Laboratory, written commun., 2010); thus, concentrations of bisphenol A and pentachlorophenol were removed for this report by coding concentrations with an "R."

For compounds detected in 50 percent or more of an individual Study Unit's field blank samples, all environmental and quality-control data for that Study Unit were removed for this report by coding concentrations with an "R." After these concentrations were removed, compounds detected in 5 percent or more of the remaining field blank samples were evaluated, and all detections of those compounds in environmental samples that were less than or equal to the highest blank concentration were censored by coding environmental concentrations with a " $\mathrm{C}<$ " in the remark columns and by changing the concentration to the highest blank concentration.

\section{Concentration Data}

Concentration data for the AOCs are presented in Appendix 2 for the 30 groundwater SWQAs and in Appendix 3 for the 20 surface-water SWQAs. The quality-assurance/qualitycontrol data associated with the groundwater and surfacewater SWQAs also are presented in Appendixes 2 and 3, respectively. The concentration data are presented in two formats: (1) Microsoft Excel spreadsheets, and (2) tab-delimited text files. The concentration data are presented by the primary use or source groups as defined in table 4. Concentrations for each of the 13 groups are presented either as a separate worksheet within the Excel spreadsheets, or as individual files for the tab-delimited text files.

Data are presented within each worksheet or text file in a similar order. First, the source-water (groundwater or surfacewater) and finished-water samples are presented (sample type: regular), followed by quality-assurance/quality-control samples (sample types: equipment blanks, field blanks, source solution blanks, and replicates). The sample medium indicates whether the regular sample was of groundwater (source water), surface water (source water), or finished water and whether the quality-assurance/quality-control samples were 
associated with groundwater (source water), surface water (source water), or finished water.

The concentrations presented in Appendixes 2 and 3 are not rounded; concentrations are presented as received from the laboratories, with the following exceptions: (1) concentrations for benzophenone, bisphenol A, isophorone, DEET, paranonylphenol (total), pentachlorophenol, and phenol were removed by coding concentrations with an " $\mathrm{R}$ " in the remark columns; (2) for compounds detected in 50 percent or more of an individual Study Unit's field blank samples, all environmental and quality-control data for that Study Unit were removed for this report by coding concentrations with an "R," and after removal of those data; (3) compounds detected in 5 percent or more of all field blank samples were evaluated, and all detections of those compounds in environmental samples that were less than or equal to the highest blank concentration were censored by coding environmental concentrations with a " $\mathrm{C}<$ " in the remark columns and by changing the concentration to the highest blank concentration. The remark columns indicate whether a concentration was too low to be quantified (reported as a less than $(<)$ value), censored (C), estimated (E), or removed (R).

\section{References Cited}

Agency for Toxic Substances and Disease Registry (ATSDR), 1992a, Toxicological profile for 1,2,3-trichloropropane, accessed July 30, 2010, at $h t t p: / / w w w . a t s d r . c d c . g o v /$ toxprofiles/tp57.html.

Agency for Toxic Substances and Disease Registry (ATSDR), 1992b, Toxicological profile for 2-hexanone, accessed July 30, 2010, at http://www.atsdr.cdc.gov/toxprofiles/tp44.html.

Barbash, J.E., and Reinhard, M., 1989, Abiotic dehalogenation of 1,2-dichloroethane and 1,2-dibromoethane in aqueous solution containing hydrogen sulphide: Environmental Science and Technology, v. 23, no. 11, p. 1,349-1,358.

Bender, D.A., Zogorski, J.S., Halde, M.J., and Rowe, B.L., 1999, Selection procedure and salient information for volatile organic compounds emphasized in the National WaterQuality Assessment Program: U.S. Geological Survey Open-File Report 99-182, 32 p.

Bradley, P.M., Chapelle, F.H., and Landmeyer, J.E., 2001, Effect of redox conditions on MTBE biodegradation in surface water sediments: Environmental Science and Technology, v. 35 , no. 23 , p. $4,643-4,647$.

Budavari, Susan, ed., 1989, The Merck Index (11th ed.): Rahway, N.J., Merck and Company, Inc. [variously paged].

Budavari, Susan, ed., 1996, The Merck Index (12th ed.): Whitehouse Station, N.J., Merck and Company, Inc. [variously paged].
California Environmental Protection Agency, 1999, Final prioritized candidate chemicals under consideration for carcinogenicity evaluation - fifty-four chemicals within batch \#3, accessed July 30, 2010, at http://www.oehha.ca.gov/ prop65/pdf/fbatch3.pdf.

CambridgeSoft Corporation, 2010, Chembiofinder.com database, accessed July 30, 2010, at $h t t p: / / w w w . c a m b r i d g e s o f t$. com/.

Carter, J.M., Delzer, G.C., Kingsbury, J.A., and Hopple, J.A., 2007, Concentration data for anthropogenic organic compounds in groundwater, surface water, and finished water of selected community water systems in the United States, 2002-05: U.S. Geological Survey Data Series 268, 30 p., accessed August 3, 2010, at http://pubs.usgs.gov/ $d s / 2007 / 268 /$.

Chemicalland21, 2010, Tolutraizole, accessed July 30, 2010, at http://www.chemicalland21.com/specialtychem/finechem/ TOLUTRIAZOLE.htm.

Childress, C.J.O., Foreman, W.T., Connor, B.F., and Maloney, T.J., 1999, New reporting procedures based on longterm method detection levels and some considerations for interpretations of water-quality data provided by the U.S. Geological Survey National Water Quality Laboratory: U.S. Geological Survey Open-File Report 99-193, 19 p.

Cohen, D.B., Gilmore, D., Fischer, C., and Bowes, G., 1983, Water quality and pesticides-1,2-Dichloropropane $(1,2-\mathrm{D})$ and 1,3-dichloropropene (1,3-D): Sacramento, Calif., California State Water Resources Control Board, Water Quality and Pesticides Special Projects Report No. 83-8SP.

Connor, B.F., Rose, D.L., Noriega, M.C., Murtagh, L.K., and Abney, S.R., 1998, Methods of analysis by the U.S. Geological Survey National Water Quality Laboratory-Determination of 86 volatile organic compounds in water by gas chromatography/mass spectrometry, including detections less than reporting limits: U.S. Geological Survey OpenFile Report 97-829, 78 p.

Cozzarelli, I.M., Baedecker, M.J., Eganhouse, R.P., and Goerlitz, D.F., 1994, The geochemical evolution of low-molecular-weight organic acids derived from the degradation of petroleum contaminants in groundwater: Geochimica et Cosmochimica Acta, v. 58, no. 2, p. 863-877.

Cozzarelli, I.M., Eganhouse, R.P., and Baedecker, M.J., 1990, Transformation of monoaromatic hydrocarbons to organic acids in anoxic groundwater environment: Environmental Geology, v. 16, no. 2, p. 135-141.

Delzer, G.C., and Hamilton, P.A., 2007, National Water-Quality Assessment Program - Source Water-Quality Assessments: U.S. Geological Survey Fact Sheet 2007-3069, 2 p. (Also available at http://pubs.usgs.gov/fs/2007/3069/.) 
Egli, Christine; Tschan, Thomas; Scholtz, Rudolf; Cook, A.M.; and Leisinger, Thomas, 1988, Transformation of tetrachloromethane to dichloromethane and carbon dioxide by acetobacterium woodii: Applied and Environmental Microbiology, v. 54, no. 11, p. 2,819-2,824.

Furlong, E.T., Anderson, B.D., Werner, S.L., Soliven, P.P., Coffey, L.J., and Burkhardt, M.R., 2001, Methods of analysis by the U.S. Geological Survey National Water Quality Laboratory-Determination of pesticides in water by graphitized carbon-based solid-phase extraction and high-performance liquid chromatography/mass spectrometry: U.S. Geological Survey Water-Resources Investigations Report 01-4134, 73 p.

Gilliom, R.J., Alley, W.M., and Gurtz, M.E., 1995, Design of the National Water-Quality Assessment Program-Occurrence and distribution of water-quality conditions: U.S. Geological Survey Circular 1112, 33 p.

Glassmeyer, S.T., Furlong, E.T., Kolpin, D.W., Cahill, J.D., Zaugg, S.D., Werner, S.L., Meyer, M.T., Kryak, D.D., 2005, Transport of chemical and microbial compounds from known wastewater discharges - Potential for use as indicators of human fecal contamination: Environmental Science and Technology, v. 39, p. 5,157-5,169.

Haag, W.R., and Mill, T., 1988, Effect of a subsurface sediment on hydrolysis of haloalkanes and epoxides: Environmental Science and Technology, v. 22, no. 6, p. 658-663.

Hladik, M.L., Hsiao, J.J., and Roberts, A.L., 2005, Are neutral chloroacetamide herbicide degradates of potential environmental concern? Analysis and occurrence in the Upper Chesapeake Bay: Environmental Science and Technology, v. 39 , no. 17 , p. $6,561-6,574$.

Hopple, J.A., Delzer, G.C., and Kingsbury, J.A., 2009, Anthropogenic organic compounds in source water of selected community water systems that use groundwater, 2002-05: U.S. Geological Survey Scientific Investigations Report 2009-5200, 74 p. (Also available at http://pubs.usgs.gov/ sir/2009/5200/.)

Kingsbury, J.A., Delzer, G.C., and Hamilton, P.A., 2008a, Man-made organic compounds in source water of nine community water systems that withdraw from streams, 2002-05: U.S. Geological Survey Fact Sheet 2008-3094, 6 p. (Also available at http://pubs.usgs.gov/fs/2008/3094/.)

Kingsbury, J.A., Delzer, G.C., and Hopple, J.A., 2008b, Anthropogenic organic compounds in source water of nine community water systems that withdraw from streams, 2002-05: U.S. Geological Survey Scientific Investigations Report 2008-5208, 66 p. (Also available at http://pubs.usgs. gov/sir/2008/5208/.)
Klecka, G.M., Gonsoir, S.J., and Markham, D.A., 1990, Biological transformations of 1,1,1-trichloroethane in subsurface soils and groundwater: Environmental Toxicology and Chemistry, v. 9, no. 12, p. 1,437-1,451.

Kolpin, D.W., Furlong, E.T., Meyer, M.T., Thurman, E.M., Zaugg, S.D., Barber, L.B., and Buxton, H.T., 2002, Pharmaceuticals, hormones, and other organic wastewater contaminants in U.S. streams, 1999-2000 - A national reconnaissance: Environmental Science and Technology, v. 36, no. 6, p. 1,202-1,211.

Koterba, M.T., Wilde, F.D., and Lapham, W.W., 1995, Groundwater data-collection protocols and procedures for the National Water-Quality Assessment Program - Collection and documentation of water-quality samples and related data: U.S. Geological Survey Open-File Report 95-399, $113 \mathrm{p}$.

Lee, E.A., and Strahan, A.P., 2003, Methods of analysis by the U.S. Geological Survey Organic Geochemistry Research Group-Determination of acetamide herbicides and their degradation products in water using online solid-phase extraction and liquid chromatography/mass spectrometry: U.S. Geological Survey Open-File Report 03-173, 17 p.

Lindley, C.E., Stewart, J.T., and Sandstrom, M.W., 1996, Determination of low concentrations of acetochlor in water by automated solid-phase extraction and gas chromatography with mass selective detection: Journal of Association of Official Analytical Chemists International, v. 79, no. 4, p. 962-966.

Lorah, M.M., and Olsen, L.D., 1999, Natural attenuation of chlorinated volatile organic compounds in a freshwater tidal wetland - Field evidence of anaerobic biodegradation: Water Resources Research, v. 35, no. 12, p. 3,811-3,828.

Madsen, J.F., Sandstrom, M.W., and Zaugg, S.D., 2003, Methods of analysis by the U.S. Geological Survey National Water Quality Laboratory-A method supplement for the determination of fipronil and degradates in water by gas chromatography/mass spectrometry: U.S. Geological Survey Open-File Report 02-462, 11 p.

Martin, J.D., 2002, Variability of pesticide detections and concentrations in field replicate water samples collected for the National Water-Quality Assessment Program, 1992-97: U.S. Geological Survey Water-Resources Investigations Report 01-4178, 84 p.

Megonigal, J.P., Hines, M.E., and Visscher, P.T., 2004, Anaerobic metabolism - Linkages to trace gases and aerobic processes, in Schlesinger, W.H., ed., Biogeochemistry: Oxford, United Kingdom, Elsevier-Pergamon, p. 317-424, accessed July 30, 2010, at http://serc.si.edu/labs/biogeochem/publications/Megonigal_Hines_Visscher_2004_V2.pdf. 
Munch, J.W., 1995, Method 524.2.-Measurement of purgeable organic compounds in water by capillary column gas chromatography/mass spectrometry, revision 4.1: Cincinnati, Ohio, Environmental Monitoring Systems Laboratory, U.S. Environmental Protection Agency, 48 p.

National Oceanic and Atmospheric Administration, 2008, Air Resources Laboratory, accessed July 30, 2010, at http:// www.arl.noaa.gov/faq/ac4.html.

Pankow, J.F., Rathbun, R.E., and Zogorski, J.S., 1996, Calculated volatilization rates of fuel oxygenate compounds and other gasoline-related compounds from rivers and streams: Chemosphere, v. 33, no. 5, p. 921-937.

Rose, D.L., and Sandstrom, M.W., 2003, Methods of analysis by the U.S. Geological Survey National Water Quality Laboratory-Determination of gasoline oxygenates, selected degradates, and BTEX in water by heated purge and trap/ gas chromatography/mass spectrometry: U.S. Geological Survey Water-Resources Investigations Report 03-4079, $31 \mathrm{p}$.

Sandstrom, M.W., Stroppel, M.E., Foreman, W.T., and Schroeder, M.P., 2001, Methods of analysis by the U.S. Geological Survey National Water Quality Laboratory-Determination of moderate-use pesticides and selected degradates in water by $\mathrm{C}-18$ solid-phase extraction and gas chromatography/mass spectrometry: U.S. Geological Survey WaterResources Investigations Report 01-4098, 70 p.

Scorecard, 2006, Chemical profiles, accessed December 22, 2006, at http://www.scorecard.org/chemical-profiles/index. tcl.

Spectrum Laboratories Inc., 2010a, Chemical fact sheet, accessed July 30, 2010, at http://www.speclab.com/ compound/c80626.htm.

Spectrum Laboratories Inc., 2010b, Chemical fact sheet, accessed July 30, 2010, at http://www.speclab.com/ compound/c591786.htm.

Tesoriero, A.J., Loffler, F.E., and Liebscher, Hugh, 2001, Fate and origin of 1,2-dichloropropane in an unconfined shallow aquifer: Environmental Science and Technology, v. 35, no. 3 , p. 455-461.

Toccalino, P.L., Norman, J.E., and Hitt, K.J., 2010, Quality of source water from public-supply wells in the United States, 1993-2007: U.S. Geological Survey Scientific Investigations Report 2010-5024, 209 p. (Also available at http:// pubs.usgs.gov/sir/2010/5024/.)

United Nations Environmental Programme, 2002, Methyl acrylonitrile, accessed July 30, 2010, at http://www.chem. unep.ch/irptc/sids/OECDSIDS/126987.pdf.
U.S. Environmental Protection Agency, 2006, Iodomethane risk assessment; notice of availability, accessed July 30, 2010, at http://www.epa.gov/fedrgstr/EPA-PEST/2006/January/Day-06/p28.htm.

U.S. Environmental Protection Agency, 2009, Inert (other) pesticide ingredients in pesticide products - Categorized list of inert (other) pesticide ingredients, accessed July 29, 2010, at http://www.epa.gov/opprd001/inerts/lists.html.

U.S. Environmental Protection Agency, 2010, Public drinking water systems - Facts and figures, accessed July 29, 2010, at http://www.epa.gov/safewater/pws/factoids.html.

U.S. Geological Survey, variously dated, National field manual for the collection of water-quality data: U.S. Geological Survey Techniques of Water-Resources Investigations, book 9, chaps. A1-A9, accessed July 29, 2010, at http://pubs. water.usgs.gov/twri9A.

U.S. Geological Survey, 2003, Principal aquifers of the 48 conterminous United States, Hawaii, Puerto Rico, and the U.S. Virgin Islands, accessed March 1, 2007, at http://www. nationalatlas.gov/mld/aquifrp.html.

U.S. Geological Survey, 2007, Toxic Substances Hydrology Program - Fuel oxygenates, accessed January 17, 2007, at http://toxics.usgs.gov/definitions/fuel_oxygenates.html.

U.S. National Library of Medicine, 2010, Household products database, accessed July 30, 2010, at http://householdproducts.nlm.nih.gov/.

U.S. National Library of Medicine, 2006, TOXNET-Toxicology data network, accessed December 22, 2006, at http:// toxnet.nlm.nih.gov/.

Valder, J.F., Delzer, G.C., Price, C.V., and Sandstrom, M.W., 2008, Study design and percent recoveries of anthropogenic organic compounds with and without the addition of ascorbic acid to preserve water samples containing free chlorine, 2004-06: U.S. Geological Survey Open-File Report 2008-1226, 85 p., accessed October 6, 2010, at http://pubs. usgs.gov/of/2008/1226/.

Vogel, T.M., and McCarty, P.L., 1985, Biotransformation of tetrachloroethylene to trichloroethylene, dichloroethylene, vinyl chloride, and carbon dioxide under methanogenic conditions: Applied and Environmental Microbiology, v. 49, no. 5, p. 1,080-1,083.

Wiedemeier, T.H., Swanson, M.A., Wilson, J.T., Kampbell, D.H., Miller, R.H., and Hansen, J.E., 1996, Approximation of biodegradation rate constants for monoaromatic hydrocarbons (BTEX) in groundwater: Groundwater Monitoring and Remediation, v.16, no. 3, p. 186-194. 
Wood, Alan, 2010, Compendium of pesticide common names, accessed July 29, 2010, at $h t t p: / / w w w . a l a n w o o d . n e t / p e s t i-$ cides/index_cn_frame.html.

Zaugg, S.D., Sandstrom, M.W., Smith, S.G., and Fehlberg, K.M., 1995, Methods of analysis by the U.S. Geological Survey National Water Quality Laboratory-Determination of pesticides in water by $\mathrm{C}-18$ solid-phase extraction and capillary-column gas chromatography/mass spectrometry with selected-ion monitoring: U.S. Geological Survey Open-File Report 95-181, 49 p.

Zaugg, S.D., Smith, S.G., Schroeder, M.P., Barber, L.B., and Burkhardt, M.R., 2002, Methods of analysis by the U.S. Geological Survey National Water Quality LaboratoryDetermination of wastewater compounds by polystyrenedivinylbenzene solid-phase extraction and capillary-column gas chromatography/mass spectrometry: U.S. Geological Survey Water-Resources Investigations Report 01-4186, $37 \mathrm{p}$.

Zogorski, J.S., Carter, J.M., Ivahnenko, Tamara, Lapham, W.W., Moran, M.J., Rowe, B.L., Squillace, P.J., and Toccalino, P.L, 2006, The quality of our Nation's watersVolatile organic compounds in the Nation's groundwater and drinking-water supply wells: U.S. Geological Survey Circular 1292, $101 \mathrm{p}$. 

Appendix 1. Compounds analyzed in Source WaterQuality Assessment studies by primary use or source groups 
Appendix 1. Compounds analyzed in Source Water-Quality Assessment studies by primary use or source groups.

[USGS, U.S. Geological Survey; CASRN, Chemical Abstracts Service Registry Number ${ }^{\mathbb{\circledR}}$; --, no additional information]

\begin{tabular}{|c|c|c|c|c|c|}
\hline $\begin{array}{l}\text { USGS } \\
\text { analytical } \\
\text { schedule }\end{array}$ & $\begin{array}{c}\text { Compound name } \\
\text { (abbreviation or other } \\
\text { name) }\end{array}$ & $\begin{array}{c}\text { USGS } \\
\text { parameter } \\
\text { code }\end{array}$ & CASRNa & Secondary uses or sources & References for use and source information \\
\hline \multicolumn{6}{|c|}{ Disinfection by-products } \\
\hline SH2020 & $\begin{array}{l}\text { Bromodichlorometh- } \\
\text { ane }\end{array}$ & 32101 & $75-27-4$ & Trihalomethane, organic synthesis, fire extinguishers & $\begin{array}{l}\text { Bender and others, 1999; U.S. National Library of } \\
\text { Medicine, } 2006 .\end{array}$ \\
\hline SH2020 & Bromoform & 32104 & $75-25-2$ & $\begin{array}{l}\text { Trihalomethane, solvent, pharmaceutical manufac- } \\
\text { turing, organic synthesis, fire extinguishers, heavy } \\
\text { liquid for mineral separations, reagent for graphite } \\
\text { ore extraction }\end{array}$ & $\begin{array}{l}\text { Bender and others, 1999; Glassmeyer and others, } \\
\text { 2005; U.S. National Library of Medicine, 2006; } \\
\text { Zogorski and others, } 2006 .\end{array}$ \\
\hline SH2020 & Chloroform & 32106 & $67-66-3$ & $\begin{array}{l}\text { Trihalomethane, fumigant, solvent, anaerobic degra- } \\
\text { date of carbon tetrachloride, used in synthesis of } \\
\text { refrigerants, extractant, chemical intermediate }\end{array}$ & $\begin{array}{l}\text { Egli and others, 1988; Bender and others, 1999; } \\
\text { Scorecard, 2006; Zogorski and others, } 2006 .\end{array}$ \\
\hline SH2020 & $\begin{array}{l}\text { Dibromochlorometh- } \\
\text { ane }\end{array}$ & 32105 & $124-48-1$ & $\begin{array}{l}\text { Trihalomethane, organic synthesis, chemical inter- } \\
\text { mediate for manufacture of aerosol propellants, } \\
\text { refrigerant, pesticides, fire extinguishing agent }\end{array}$ & $\begin{array}{l}\text { Bender and others, 1999; U.S. National Library of } \\
\text { Medicine, 2006; Zogorski and others, } 2006 .\end{array}$ \\
\hline \multicolumn{6}{|c|}{ Fumigant-related compounds } \\
\hline SH2020 & $\begin{array}{l}\text { 1,2-Dibromo-3-chloro- } \\
\text { propane }(\mathrm{DBCP})\end{array}$ & 82625 & $96-12-8$ & Organic synthesis, nematocide & Budavari, 1989; Zogorski and others, 2006. \\
\hline SH2020 & $\begin{array}{l}\text { 1,2-Dibromoethane } \\
\text { (EDB) }\end{array}$ & 77651 & $106-93-4$ & $\begin{array}{l}\text { Anti-knock compound in gasoline, former pesticide, } \\
\text { solvent, waterproofing preparations, dyes, and } \\
\text { pharmaceuticals }\end{array}$ & $\begin{array}{l}\text { Budavari, 1989; National Oceanic and Atmospheric } \\
\text { Administration, 2008; Scorecard, 2006; U.S. } \\
\text { National Library of Medicine, 2006; Zogorski and } \\
\text { others, } 2006 .\end{array}$ \\
\hline SH2020 & 1,2-Dichloropropane & 34541 & $78-87-5$ & $\begin{array}{l}\text { Dry-cleaning solvent, chemical intermediate, stain } \\
\text { remover }\end{array}$ & $\begin{array}{l}\text { Budavari, 1989, 1996; Tesoriero and others, 2001; } \\
\text { Zogorski and others, } 2006 .\end{array}$ \\
\hline SH2020 & 1,3-Dichloropropane & 77173 & $142-28-9$ & Fumigant contaminant & Bender and others, 1999. \\
\hline SH2020 & $\begin{array}{l}\text { 1,4-Dichlorobenzene } \\
\text { (p-dichlorobenzene) }\end{array}$ & 34571 & $106-46-7$ & $\begin{array}{l}\text { Deodorizer, moth killer, manufacture of dyes, chemi- } \\
\text { cal intermediate }\end{array}$ & $\begin{array}{l}\text { Bender and others, 1999; Zaugg and others, 2002; } \\
\text { Glassmeyer and others, 2005; Scorecard, } 2006 .\end{array}$ \\
\hline SH2020 & 2,2-Dichloropropane & 77170 & $594-20-7$ & Fumigant contaminant & Cohen and others, 1983; Bender and others, 1999. \\
\hline SH 2020 & $\begin{array}{l}\text { Bromomethane } \\
\text { (methyl bromide) }\end{array}$ & 34413 & $74-83-9$ & Solvent, chemical intermediate & Bender and others, 1999; Zogorski and others, 2006. \\
\hline SH2020 & $\begin{array}{l}\text { cis-1,3-Dichloropro- } \\
\text { pene }\end{array}$ & 34704 & $10061-01-5$ & Solvent, chemical intermediate & Bender and others, 1999; Zogorski and others, 2006. \\
\hline SH2020 & $\begin{array}{l}\text { trans-1,3-Dichloropro- } \\
\text { pene }\end{array}$ & 34699 & $10061-02-6$ & Solvent, chemical intermediate & Bender and others, 1999; Zogorski and others, 2006. \\
\hline \multicolumn{6}{|c|}{ Fungicides and fungicide degradates } \\
\hline SH2033 & 3,5-Dichloroaniline & 61627 & $626-43-7$ & -- & Sandstrom and others, 2001. \\
\hline SH2060 & Benomyl & 50300 & $17804-35-2$ & -- & Furlong and others, 2001; Wood, 2010. \\
\hline
\end{tabular}


Appendix 1. Compounds analyzed in Source Water-Quality Assessment studies by primary use or source groups.-Continued

[USGS, U.S. Geological Survey; CASRN, Chemical Abstracts Service Registry Number ${ }^{\circledR}$; --, no additional information]

\begin{tabular}{|c|c|c|c|c|c|}
\hline $\begin{array}{l}\text { USGS } \\
\text { analytical } \\
\text { schedule }\end{array}$ & $\begin{array}{l}\text { Compound name } \\
\text { (abbreviation or other } \\
\text { name) }\end{array}$ & $\begin{array}{l}\text { USGS } \\
\text { parameter } \\
\text { code }\end{array}$ & CASRNa & Secondary uses or sources & References for use and source information \\
\hline \multicolumn{6}{|c|}{ Fungicides and fungicide degradates - Continued } \\
\hline SH2060 & Chlorothalonil & 49306 & $1897-45-6$ & -- & Furlong and others, 2001. \\
\hline SH2033 & cis-Propiconazole & 79846 & $\mathrm{c}-60207-90-1^{\mathrm{b}}$ & -- & Sandstrom and others, 2001. \\
\hline SH2003/2033 & Iprodione & 61593 & $36734-19-7$ & -- & Sandstrom and others, 2001; Wood, 2010. \\
\hline SH2003/2033 & Metalaxyl & 61596 & $57837-19-1$ & -- & $\begin{array}{l}\text { Furlong and others, 2001; Glassmeyer and others, } \\
\text { 2005; Wood, } 2010 .\end{array}$ \\
\hline SH2003/2033 & Myclobutanil & 61599 & $88671-89-0$ & -- & Sandstrom and others, 2001: Wood, 2010. \\
\hline SH1433 & Pentachlorophenol & 34459 & $87-86-5$ & $\begin{array}{l}\text { Wood preservative, herbicide, insecticide, plant } \\
\text { growth regulator }\end{array}$ & $\begin{array}{l}\text { Zaugg and others, 2002; Glassmeyer and others, } \\
\text { 2005; Scorecard, 2006; Wood, } 2010 .\end{array}$ \\
\hline SH2060 & Propiconazole & 50471 & $60207-90-1$ & -- & Furlong and others, 2001; Wood, 2010. \\
\hline SH2033 & Tebuconazole & 62852 & $107534-96-3$ & -- & Wood, 2010. \\
\hline SH2033 & trans-Propiconazole & 79847 & $\mathrm{t}-60207-90-1^{\mathrm{b}}$ & -- & Sandstrom and others, 2001. \\
\hline \multicolumn{6}{|c|}{ Gasoline hydrocarbons, oxygenates, and oxygenate degradates } \\
\hline SH2020 & $\begin{array}{l}\text { 1,2,3,4-Tetramethyl- } \\
\text { benzene }\end{array}$ & 49999 & $488-23-3$ & Petroleum hydrocarbon & Cozzarelli and others, 1994. \\
\hline SH2020 & $\begin{array}{l}\text { 1,2,3,5-Tetramethyl- } \\
\text { benzene }\end{array}$ & 50000 & $527-53-7$ & Petroleum hydrocarbon & Cozzarelli and others, 1990. \\
\hline SH2020 & $\begin{array}{l}\text { 1,2,3-Trimethylben- } \\
\text { zene }\end{array}$ & 77221 & $526-73-8$ & Gasoline hydrocarbon, pesticide adjuvant & $\begin{array}{l}\text { Wiedemeier and others, 1996; U.S. Environmental } \\
\text { Protection Agency, } 2009 .\end{array}$ \\
\hline SH2020 & $\begin{array}{l}\text { 1,2,4-Trimethylben- } \\
\text { zene }\end{array}$ & 77222 & $95-63-6$ & $\begin{array}{l}\text { Petroleum hydrocarbon, pesticide adjuvant, chemical } \\
\text { intermediate }\end{array}$ & $\begin{array}{l}\text { Cozzarelli and others, 1990; Wiedemeier and others, } \\
\text { 1996; U.S. Environmental Protection Agency, } \\
\text { 2009; U.S. National Library of Medicine, } 2006 .\end{array}$ \\
\hline SH2020 & $\begin{array}{l}\text { 1,3,5-Trimethylben- } \\
\text { zene }\end{array}$ & 77226 & $108-67-8$ & $\begin{array}{l}\text { Used in synthesis of Ethanox 330, gasoline hydro- } \\
\text { carbon }\end{array}$ & $\begin{array}{l}\text { Wiedemeier and others, 1996; U.S. National Library } \\
\text { of Medicine, } 2006 .\end{array}$ \\
\hline SH2020 & $\begin{array}{l}\text { 1-Ethyl-2-methylben- } \\
\text { zene }\end{array}$ & 77220 & $611-14-3$ & Petroleum hydrocarbon & $\begin{array}{l}\text { Cozzarelli and others, 1990; Zogorski and others, } \\
2006 .\end{array}$ \\
\hline SH1433 & 1-Methylnaphthalene & 62054 & $90-12-0$ & $\begin{array}{l}\text { Polynuclear aromatic hydrocarbon, pesticide ad- } \\
\text { juvant, wall coverings, gasoline and diesel fuel } \\
\text { component }\end{array}$ & $\begin{array}{l}\text { Zaugg and others, 2002; Glassmeyer and others, } \\
\text { 2005; Scorecard, 2006; U.S. Environmental Pro- } \\
\text { tection Agency, } 2009 .\end{array}$ \\
\hline SH1433 & $\begin{array}{l}\text { 2,6-Dimethylnaphtha- } \\
\text { lene }\end{array}$ & 62055 & $581-42-0$ & $\begin{array}{l}\text { Polynuclear aromatic hydrocarbon, diesel fuel com- } \\
\text { ponent, pesticide adjuvant, insecticide }\end{array}$ & $\begin{array}{l}\text { Zaugg and others, 2002; Glassmeyer and others, } \\
\text { 2005; Scorecard, 2006; U.S. Environmental Pro- } \\
\text { tection Agency, 2009. }\end{array}$ \\
\hline SH1433 & 2-Methylnaphthalene & 62056 & $91-57-6$ & $\begin{array}{l}\text { Polynuclear aromatic hydrocarbon, pesticide adju- } \\
\text { vant, sealants, adhesives, wall coverings, gasoline } \\
\text { and diesel fuel component }\end{array}$ & $\begin{array}{l}\text { Zaugg and others, 2002; Glassmeyer and others, } \\
\text { 2005; Scorecard, 2006; U.S. Environmental Pro- } \\
\text { tection Agency, } 2009 .\end{array}$ \\
\hline
\end{tabular}


Appendix 1. Compounds analyzed in Source Water-Quality Assessment studies by primary use or source groups.-Continued

[USGS, U.S. Geological Survey; CASRN, Chemical Abstracts Service Registry Number ${ }^{\circledR}$; --, no additional information]

\begin{tabular}{|c|c|c|c|c|c|}
\hline $\begin{array}{c}\text { USGS } \\
\text { analytical } \\
\text { schedule }\end{array}$ & $\begin{array}{c}\text { Compound name } \\
\text { (abbreviation or other } \\
\text { name) }\end{array}$ & $\begin{array}{c}\text { USGS } \\
\text { parameter } \\
\text { code }\end{array}$ & CASRNa & Secondary uses or sources & References for use and source information \\
\hline \multicolumn{6}{|c|}{ Gasoline hydrocarbons, oxygenates, and oxygenate degradates-Continued } \\
\hline SH2020 & Benzene & 34030 & $71-43-2$ & Gasoline hydrocarbon, organic synthesis & $\begin{array}{l}\text { Bender and others, 1999; U.S. National Library of } \\
\text { Medicine, } 2006 .\end{array}$ \\
\hline SH2020 & $\begin{array}{l}\text { Diisopropyl ether } \\
\text { (DIPE) }\end{array}$ & 81577 & $108-20-3$ & Gasoline oxygenate, solvent & Bender and others, 1999. \\
\hline SH2020 & $\begin{array}{l}\text { Ethyl tert-butyl ether } \\
\text { (ETBE) }\end{array}$ & 50004 & $637-92-3$ & Gasoline oxygenate & Bender and others, 1999. \\
\hline SH2020 & Ethylbenzene & 34371 & $100-41-4$ & $\begin{array}{l}\text { Gasoline hydrocarbon, organic synthesis, solvent, } \\
\text { pesticide adjuvant }\end{array}$ & $\begin{array}{l}\text { Bender and others, 1999; U.S. National Library of } \\
\text { Medicine, 2006; U.S. Environmental Protection } \\
\text { Agency, 2009. }\end{array}$ \\
\hline SH2020 & Isopropylbenzene & 77223 & $98-82-8$ & $\begin{array}{l}\text { Organic synthesis, building materials, solvent, } \\
\text { gasoline hydrocarbon, intermediate in production } \\
\text { of plastics }\end{array}$ & $\begin{array}{l}\text { Bender and others, 1999; Glassmeyer and others, } \\
2005 .\end{array}$ \\
\hline SH2020 & $m$ - \& p-Xylene & 85795 & $\begin{array}{l}106-42-3 \\
108-38-3\end{array}$ & Gasoline hydrocarbon, solvent, organic synthesis & $\begin{array}{l}\text { U.S. National Library of Medicine, 2006; Zogorski } \\
\text { and others, } 2006 .\end{array}$ \\
\hline SH2020 & $\begin{array}{l}\text { Methyl tert-butyl ether } \\
\text { (MTBE) }\end{array}$ & 78032 & $1634-04-4$ & Gasoline oxygenate & Bender and others, 1999. \\
\hline SH2020 & Naphthalene & 34696 & $91-20-3$ & $\begin{array}{l}\text { Polynuclear aromatic hydrocarbon, petroleum hy- } \\
\text { drocarbon, pesticide adjuvant, combustion prod- } \\
\text { uct, disinfectant, antiseptic, mouthwash, throat } \\
\text { lozenges, slimicides, manufacture of synthetic } \\
\text { fibers, fumigant, moth repellant }\end{array}$ & $\begin{array}{l}\text { Bender and others, 1999; Glassmeyer and others, } \\
\text { 2005; U.S. National Library of Medicine, } 2006 .\end{array}$ \\
\hline SH2020 & $n$-Butylbenzene & 77342 & $104-51-8$ & Solvent, organic synthesis & $\begin{array}{l}\text { Bender and others, 1999; U.S. National Library of } \\
\text { Medicine, 2006; Zogorski and others, } 2006 .\end{array}$ \\
\hline SH2020 & $o$-Xylene & 77135 & $95-47-6$ & $\begin{array}{l}\text { Gasoline hydrocarbon, pesticide adjuvant, organic } \\
\text { synthesis, solvent }\end{array}$ & $\begin{array}{l}\text { Bender and others, 1999; U.S. National Library of } \\
\text { Medicine, } 2006 .\end{array}$ \\
\hline SH2020 & $\begin{array}{l}p \text {-Isopropyltoluene } \\
\quad(p \text {-cymene })\end{array}$ & 77356 & $99-87-6$ & $\begin{array}{l}\text { Organic synthesis, solvent, heat transfer agent, wood } \\
\text { office furniture }\end{array}$ & $\begin{array}{l}\text { Bender and others, 1999; Scorecard, 2006; U.S. } \\
\text { National Library of Medicine, } 2006 .\end{array}$ \\
\hline SH2020 & sec-Butylbenzene & 77350 & $135-98-8$ & $\begin{array}{l}\text { Gasoline hydrocarbon, solvent, organic synthesis, } \\
\text { plasticizer }\end{array}$ & $\begin{array}{l}\text { Bender and others, 1999; U.S. National Library of } \\
\text { Medicine, } 2006 .\end{array}$ \\
\hline SH2020 & Styrene & 77128 & $100-42-5$ & $\begin{array}{l}\text { Organic synthesis, manufacture of styrofoam, build- } \\
\text { ing materials, adhesives }\end{array}$ & $\begin{array}{l}\text { Bender and others, 1999; Scorecard, 2006; U.S. } \\
\text { National Library of Medicine, 2006; Zogorski and } \\
\text { others, } 2006 .\end{array}$ \\
\hline SH4024 & $\begin{array}{l}\text { tert-Amyl alcohol } \\
\text { (2-methyl-2-buta- } \\
\text { nol) }\end{array}$ & 77073 & $75-85-4$ & Gasoline oxygenate & U.S. Geological Survey, 2007. \\
\hline SH2020 & tert-Amyl methyl ether & 50005 & $994-05-8$ & Gasoline oxygenate & Bender and others, 1999. \\
\hline
\end{tabular}


Appendix 1. Compounds analyzed in Source Water-Quality Assessment studies by primary use or source groups.-Continued

[USGS, U.S. Geological Survey; CASRN, Chemical Abstracts Service Registry Number ${ }^{\mathbb{}}$; --, no additional information]

\begin{tabular}{|c|c|c|c|c|c|}
\hline $\begin{array}{c}\text { USGS } \\
\text { analytical } \\
\text { schedule }\end{array}$ & $\begin{array}{c}\text { Compound name } \\
\text { (abbreviation or other } \\
\text { name) }\end{array}$ & $\begin{array}{c}\text { USGS } \\
\text { parameter } \\
\text { code } \\
\end{array}$ & CASRNa & Secondary uses or sources & References for use and source information \\
\hline \multicolumn{6}{|c|}{ Gasoline hydrocarbons, oxygenates, and oxygenate degradates-Continued } \\
\hline SH4024 & tert-Butyl alcohol & 77035 & $75-65-0$ & $\begin{array}{l}\text { Gasoline oxygenate; methyl tert-butyl ether (MTBE) } \\
\text { degradate }\end{array}$ & $\begin{array}{l}\text { Pankow and others, 1996; Bradley and others, 2001; } \\
\text { U.S. Geological Survey, } 2007 .\end{array}$ \\
\hline SH2020 & tert-Butylbenzene & 77353 & $98-06-6$ & Organic synthesis & $\begin{array}{l}\text { Bender and others, 1999; U.S. National Library of } \\
\text { Medicine, } 2006 .\end{array}$ \\
\hline SH2020 & Toluene & 34010 & $108-88-3$ & Solvent consumer products, pesticide adjuvant & $\begin{array}{l}\text { Bender and others, 1999; U.S. Environmental Pro- } \\
\text { tection Agency, } 2009 .\end{array}$ \\
\hline \multicolumn{6}{|c|}{ Herbicides and herbicide degradates } \\
\hline SH2060 & $2,4-\mathrm{D}$ & 39732 & $94-75-7$ & -- & Furlong and others, 2001. \\
\hline SH2060 & 2,4-D methyl ester & 50470 & $1928-38-7$ & -- & Furlong and others, 2001. \\
\hline SH2060 & $2,4-\mathrm{DB}$ & 38746 & $94-82-6$ & -- & Furlong and others, 2001. \\
\hline SH2003/2033 & 2,6-Diethylaniline & 82660 & $579-66-8$ & Herbicide (mostly alachlor) degradate & Zaugg and others, 1995; Hladik and others, 2005. \\
\hline SH2003/2033 & $\begin{array}{l}\text { 2-Chloro-2,6-diethyl- } \\
\text { acetanilide }\end{array}$ & 61618 & $6967-29-9$ & Herbicide (mostly alachlor) degradate & $\begin{array}{l}\text { Sandstrom and others, 2001; Hladik and others, } \\
2005 .\end{array}$ \\
\hline SH2003/2033 & $\begin{array}{l}\text { 2-Ethyl-6-methyl- } \\
\text { aniline }\end{array}$ & 61620 & $24549-06-2$ & Herbicide (acetochlor or metolachlor) degradate & $\begin{array}{l}\text { Sandstrom and others, 2001; Hladik and others, } \\
2005 .\end{array}$ \\
\hline SH2060 & 2-Hydroxyatrazine & 50355 & $2163-68-0$ & Herbicide (atrazine) degradate & Furlong and others, 2001. \\
\hline SH2060 & $\begin{array}{l}\text { 3(4-Chlorophenyl)-1- } \\
\text { methyl urea }\end{array}$ & 61692 & $5352-88-5$ & Herbicide degradate & Furlong and others, 2001. \\
\hline SH2003/2033 & 3,4-Dichloroaniline & 61625 & $95-76-1$ & Herbicide (diuron) degradate & Sandstrom and others, 2001. \\
\hline SH2003/2033 & $\begin{array}{l}\text { 4-Chloro-2-methyl- } \\
\text { phenol }\end{array}$ & 61633 & $1570-64-5$ & Herbicide (MCPA) degradate & Sandstrom and others, 2001. \\
\hline SH2003/2033 & Acetochlor & 49260 & $34256-82-1$ & -- & Lee and Strahan, 2003. \\
\hline LCPD & $\begin{array}{l}\text { Acetochlor ethane } \\
\text { sulfonic acid }\end{array}$ & 61029 & $187022-11-3$ & Herbicide (acetochlor) degradate & Lee and Strahan, 2003. \\
\hline LCPD & $\begin{array}{l}\text { Acetochlor oxanilic } \\
\text { acid }\end{array}$ & 61030 & $184992-44-4$ & Herbicide (acetochlor) degradate & Lee and Strahan, 2003. \\
\hline LCPD & $\begin{array}{l}\text { Acetochlor sulfynil- } \\
\text { acetic acid }\end{array}$ & 62847 & -- & Herbicide (acetochlor) degradate & Lee and Strahan, 2003. \\
\hline LCPD & $\begin{array}{l}\text { Acetochlor/meto- } \\
\text { lachlor ethane } \\
\text { sulfonic acid 2nd } \\
\text { amide }\end{array}$ & 62850 & -- & Herbicide (acetochlor or metolachlor) degradate & Lee and Strahan, 2003. \\
\hline SH2060 & Acifluorfen & 49315 & $50594-66-6$ & -- & Furlong and others, 2001. \\
\hline SH2003/2033 & Alachlor & 46342 & $15972-60-8$ & -- & Zaugg and others, 1995. \\
\hline
\end{tabular}


Appendix 1. Compounds analyzed in Source Water-Quality Assessment studies by primary use or source groups.-Continued

[USGS, U.S. Geological Survey; CASRN, Chemical Abstracts Service Registry Number ${ }^{\mathbb{}}$; --, no additional information]

\begin{tabular}{|c|c|c|c|c|c|}
\hline $\begin{array}{l}\text { USGS } \\
\text { analytical } \\
\text { schedule }\end{array}$ & $\begin{array}{c}\text { Compound name } \\
\text { (abbreviation or other } \\
\text { name) }\end{array}$ & $\begin{array}{c}\text { USGS } \\
\text { parameter } \\
\text { code }\end{array}$ & CASRNa & Secondary uses or sources & References for use and source information \\
\hline \multicolumn{6}{|c|}{ Herbicides and herbicide degradates-Continued } \\
\hline LCPD & $\begin{array}{l}\text { Alachlor ethane sul- } \\
\text { fonic acid }\end{array}$ & 50009 & $142363-53-9$ & Herbicide (alachlor) degradate & Lee and Strahan, 2003. \\
\hline LCPD & $\begin{array}{l}\text { Alachlor ethane } \\
\text { sulfonic acid 2nd } \\
\text { amide }\end{array}$ & 62849 & -- & Herbicide (alachlor) degradate & Lee and Strahan, 2003. \\
\hline LCPD & Alachlor oxanilic acid & 61031 & $171262-17-2$ & Herbicide (alachlor) degradate & Lee and Strahan, 2003. \\
\hline LCPD & $\begin{array}{l}\text { Alachlor sulfynilacetic } \\
\text { acid }\end{array}$ & 62848 & $140939-16-8$ & Herbicide (alachlor) degradate & Lee and Strahan, 2003. \\
\hline SH2003/2033 & Atrazine & 39632 & $1912-24-9$ & -- & $\begin{array}{l}\text { Zaugg and others, 1995; Glassmeyer and others, } \\
2005 .\end{array}$ \\
\hline SH2003/2033 & Benfluralin & 82673 & $1861-40-1$ & -- & Zaugg and others, 1995. \\
\hline SH2060 & Bensulfuron-methyl & 61693 & $83055-99-6$ & -- & Furlong and others, 2001. \\
\hline SH2060 & Bentazon & 38711 & $25057-89-0$ & -- & Furlong and others, 2001. \\
\hline SH2060 & Bromacil & 04029 & $314-40-9$ & -- & $\begin{array}{l}\text { Furlong and others, 2001; Glassmeyer and others, } \\
2005 .\end{array}$ \\
\hline SH2060 & Bromoxynil & 49311 & $1689-84-5$ & -- & Furlong and others, 2001. \\
\hline SH2060 & $\begin{array}{l}\text { Chloramben, methyl } \\
\text { ester }\end{array}$ & 61188 & $7286-84-2$ & -- & Furlong and others, 2001. \\
\hline SH2060 & Chlorimuron-ethyl & 50306 & $90982-32-4$ & -- & Furlong and others, 2001. \\
\hline SH2060 & Clopyralid & 49305 & $1702-17-6$ & -- & Furlong and others, 2001. \\
\hline SH2033 & Cyanazine & 04041 & $21725-46-2$ & -- & Zaugg and others, 1995. \\
\hline SH2060 & Cycloate & 04031 & $1134-23-2$ & -- & Furlong and others, 2001. \\
\hline SH2003/2033 & Dacthal & 82682 & $1861-32-1$ & -- & Zaugg and others, 1995. \\
\hline SH2060 & Dacthal monoacid & 49304 & $887-54-7$ & Herbicide (dacthal) degradate & Furlong and others, 2001. \\
\hline SH2003/2033 & Deethylatrazine & 04040 & $6190-65-4$ & Herbicide (atrazine) degradate & Zaugg and others, 1995. \\
\hline SH2060 & $\begin{array}{l}\text { Deethyldeisopropyl- } \\
\text { atrazine }\end{array}$ & 04039 & $3397-62-4$ & Herbicide (atrazine) degradate & Furlong and others, 2001. \\
\hline SH2060 & Deisopropylatrazine & 04038 & $1007-28-9$ & Herbicide (atrazine) degradate & Furlong and others, 2001. \\
\hline SH2060 & Dicamba & 38442 & $1918-00-9$ & -- & Furlong and others, 2001. \\
\hline SH2060 & Dichlorprop & 49302 & $120-36-5$ & -- & Furlong and others, 2001. \\
\hline LCPD & Dimethenamid & 61588 & $87674-68-8$ & -- & Lee and Strahan, 2003. \\
\hline LCPD & $\begin{array}{l}\text { Dimethenamid ethane } \\
\text { sulfonic acid }\end{array}$ & 61951 & $205939-58-8$ & Herbicide (dimethenamid) degradate & Lee and Strahan, 2003. \\
\hline
\end{tabular}


Appendix 1. Compounds analyzed in Source Water-Quality Assessment studies by primary use or source groups.-Continued

[USGS, U.S. Geological Survey; CASRN, Chemical Abstracts Service Registry Number ${ }^{\mathbb{B}}$; --, no additional information]

\begin{tabular}{|c|c|c|c|c|c|}
\hline $\begin{array}{c}\text { USGS } \\
\text { analytical } \\
\text { schedule }\end{array}$ & $\begin{array}{c}\text { Compound name } \\
\text { (abbreviation or other } \\
\text { name) }\end{array}$ & $\begin{array}{c}\text { USGS } \\
\text { parameter } \\
\text { code }\end{array}$ & CASRNa $^{a}$ & Secondary uses or sources & References for use and source information \\
\hline \multicolumn{6}{|c|}{ Herbicides and herbicide degradates-Continued } \\
\hline LCPD & $\begin{array}{l}\text { Dimethenamid oxa- } \\
\text { nilic acid }\end{array}$ & 62482 & -- & Herbicide (dimethenamid) degradate & Lee and Strahan, 2003. \\
\hline SH2060 & Dinoseb & 49301 & $88-85-7$ & Plant growth regulator & Furlong and others, 2001. \\
\hline SH2060 & Diphenamid & 04033 & $957-51-7$ & -- & Furlong and others, 2001. \\
\hline SH2060 & Diuron & 49300 & $330-54-1$ & -- & Furlong and others, 2001. \\
\hline SH2033 & EPTC & 82668 & $759-94-4$ & -- & Zaugg and others, 1995; Wood, 2010. \\
\hline SH2060 & Fenuron & 49297 & $101-42-8$ & -- & Furlong and others, 2001. \\
\hline LCPD & Flufenacet & 62481 & $142459-58-3$ & -- & Lee and Strahan, 2003. \\
\hline LCPD & $\begin{array}{l}\text { Flufenacet ethane } \\
\text { sulfonic acid }\end{array}$ & 61952 & -- & Herbicide (flufenacet) degradate & Lee and Strahan, 2003. \\
\hline LCPD & $\begin{array}{l}\text { Flufenacet oxanilic } \\
\text { acid }\end{array}$ & 62483 & -- & Herbicide (flufenacet) degradate & Lee and Strahan, 2003. \\
\hline SH2060 & Flumetsulam & 61694 & $98967-40-9$ & -- & Furlong and others, 2001. \\
\hline SH2060 & Fluometuron & 38811 & $2164-17-2$ & -- & Furlong and others, 2001. \\
\hline SH2003/2033 & Hexazinone & 04025 & $51235-04-2$ & -- & Sandstrom and others, 2001. \\
\hline SH2060 & Imazaquin & 50356 & $81335-37-7$ & -- & Furlong and others, 2001. \\
\hline SH2060 & Imazethapyr & 50407 & $81335-77-5$ & -- & Furlong and others, 2001. \\
\hline SH2060 & Linuron & 38478 & $330-55-2$ & -- & Furlong and others, 2001. \\
\hline SH2060 & MCPA & 38482 & $94-74-6$ & -- & Furlong and others, 2001. \\
\hline SH2060 & MCPB & 38487 & $94-81-5$ & -- & Furlong and others, 2001. \\
\hline SH2003/2033 & Metolachlor & 39415 & $51218-45-2$ & -- & $\begin{array}{l}\text { Zaugg and others, 1995; Glassmeyer and others, } \\
2005 .\end{array}$ \\
\hline LCPD & $\begin{array}{l}\text { Metolachlor ethane } \\
\text { sulfonic acid }\end{array}$ & 61043 & $171118-09-5$ & Herbicide (metolachlor) degradate & Lee and Strahan, 2003. \\
\hline LCPD & $\begin{array}{l}\text { Metolachlor oxanilic } \\
\text { acid }\end{array}$ & 61044 & $152019-73-3$ & Herbicide (metolachlor) degradate & Lee and Strahan, 2003. \\
\hline SH2003/2033 & Metribuzin & 82630 & $21087-64-9$ & -- & Zaugg and others, 1995. \\
\hline SH2060 & Metsulfuron methyl & 61697 & $74223-64-6$ & -- & Furlong and others, 2001. \\
\hline SH2033 & Molinate & 82671 & $2212-67-1$ & -- & Zaugg and others, 1995. \\
\hline SH2060 & Neburon & 49294 & $555-37-3$ & -- & Furlong and others, 2001. \\
\hline SH 2060 & Nicosulfuron & 50364 & $111991-09-4$ & -- & Furlong and others, 2001. \\
\hline SH2060 & Norflurazon & 49293 & $27314-13-2$ & -- & Furlong and others, 2001. \\
\hline
\end{tabular}


Appendix 1. Compounds analyzed in Source Water-Quality Assessment studies by primary use or source groups.-Continued

[USGS, U.S. Geological Survey; CASRN, Chemical Abstracts Service Registry Number ${ }^{\mathbb{\circledR}}$; --, no additional information]

\begin{tabular}{|c|c|c|c|c|c|}
\hline $\begin{array}{c}\text { USGS } \\
\text { analytical } \\
\text { schedule }\end{array}$ & $\begin{array}{c}\text { Compound name } \\
\text { (abbreviation or other } \\
\text { name) }\end{array}$ & $\begin{array}{c}\text { USGS } \\
\text { parameter } \\
\text { code }\end{array}$ & CASRNa & Secondary uses or sources & References for use and source information \\
\hline \multicolumn{6}{|c|}{ Herbicides and herbicide degradates-Continued } \\
\hline SH2060 & Oryzalin & 49292 & $19044-88-3$ & -- & Furlong and others, 2001. \\
\hline SH2033 & Oxyfluorfen & 61600 & $42874-03-3$ & -- & Sandstrom and others, 2001. \\
\hline SH2003/2033 & Pendimethalin & 82683 & $40487-42-1$ & -- & Zaugg and others, 1995. \\
\hline SH2060 & Picloram & 49291 & $1918-02-1$ & -- & Furlong and others, 2001. \\
\hline SH2003/2033 & Prometon & 04037 & $1610-18-0$ & -- & $\begin{array}{l}\text { Zaugg and others, 1995; Glassmeyer and others, } \\
2005 .\end{array}$ \\
\hline SH2003/2033 & Prometryn & 04036 & $7287-19-6$ & -- & Sandstrom and others, 2001. \\
\hline LCPD & Propachlor & 04024 & $1918-16-7$ & -- & Lee and Strahan, 2003. \\
\hline LCPD & $\begin{array}{l}\text { Propachlor ethane } \\
\text { sulfonic acid }\end{array}$ & 62766 & -- & Herbicide (propachlor) degradate & Lee and Strahan, 2003. \\
\hline LCPD & $\begin{array}{l}\text { Propachlor oxanilic } \\
\text { acid }\end{array}$ & 62767 & -- & Herbicide (propachlor) degradate & Lee and Strahan, 2003. \\
\hline SH2033 & Propanil & 82679 & $709-98-8$ & -- & Zaugg and others, 1995. \\
\hline SH2060 & Propham & 49236 & $122-42-9$ & -- & Furlong and others, 2001. \\
\hline SH2003/2033 & Propyzamide & 82676 & $23950-58-5$ & -- & Zaugg and others, 1995. \\
\hline SH2060 & Siduron & 38548 & $1982-49-6$ & -- & Furlong and others, 2001. \\
\hline SH2003/2033 & Simazine & 04035 & $122-34-9$ & -- & Zaugg and others, 1995. \\
\hline SH2060 & Sulfometuron-methyl & 50337 & $74222-97-2$ & -- & Furlong and others, 2001. \\
\hline SH2060/2033 & Tebuthiuron & 82670 & $34014-18-1$ & -- & Furlong and others, 2001. \\
\hline SH2060 & Terbacil & 04032 & $5902-51-2$ & -- & Furlong and others, 2001. \\
\hline SH2003/2033 & Terbuthylazine & 04022 & $5915-41-3$ & -- & Sandstrom and others, 2001. \\
\hline SH2033 & Thiobencarb & 82681 & $28249-77-6$ & -- & Zaugg and others, 1995. \\
\hline SH2060 & Triclopyr & 49235 & $55335-06-3$ & -- & Furlong and others, 2001. \\
\hline SH2003/2033 & Trifluralin & 82661 & $1582-09-8$ & -- & Zaugg and others, 1995. \\
\hline \multicolumn{6}{|c|}{ Insecticides and insecticide degradates } \\
\hline SH2003/2033 & 1-Naphthol & 49295 & $90-15-3$ & $\begin{array}{l}\text { Herbicide (napropamide) and insecticide (carbaryl) } \\
\text { degradate }\end{array}$ & Sandstrom and others, 2001. \\
\hline SH2060 & 3-Hydroxycarbofuran & 49308 & $16655-82-6$ & Insecticide (carbofuran) degradate & Furlong and others, 2001. \\
\hline SH2060 & 3-Ketocarbofuran & 50295 & 16709-30-1 & Insecticide (carbofuran) degradate & Furlong and others, 2001. \\
\hline SH2060 & Aldicarb & 49312 & $116-06-3$ & -- & Furlong and others, 2001. \\
\hline SH2060 & Aldicarb sulfone & 49313 & $1646-88-4$ & Insecticide (aldicarb) degradate & Furlong and others, 2001. \\
\hline SH2060 & Aldicarb sulfoxide & 49314 & $1646-87-3$ & Insecticide (aldicarb) degradate & Furlong and others, 2001. \\
\hline
\end{tabular}


Appendix 1. Compounds analyzed in Source Water-Quality Assessment studies by primary use or source groups.-Continued

[USGS, U.S. Geological Survey; CASRN, Chemical Abstracts Service Registry Number ${ }^{\circledR}$; --, no additional information]

\begin{tabular}{|c|c|c|c|c|c|}
\hline $\begin{array}{c}\text { USGS } \\
\text { analytical } \\
\text { schedule }\end{array}$ & $\begin{array}{c}\text { Compound name } \\
\text { (abbreviation or other } \\
\text { name) }\end{array}$ & $\begin{array}{c}\text { USGS } \\
\text { parameter } \\
\text { code }\end{array}$ & CASRN ${ }^{\mathrm{a}}$ & Secondary uses or sources & References for use and source information \\
\hline \multicolumn{6}{|c|}{ Insecticides and insecticide degradates-Continued } \\
\hline SH2033 & alpha-Endosulfan & 34362 & $959-98-8$ & -- & Sandstrom and others, 2001. \\
\hline SH2003/2033 & Azinphos-methyl & 82686 & $86-50-0$ & -- & Zaugg and others, 1995. \\
\hline SH2003/2033 & Azinphos-methyl-oxon & 61635 & $961-22-8$ & Insecticide (azinphos-methyl) degradate & Sandstrom and others, 2001. \\
\hline SH2060 & Bendiocarb & 50299 & $22781-23-3$ & -- & Furlong and others, 2001. \\
\hline SH2060/2033 & Carbaryl & $49310 / 82680$ & $63-25-2$ & -- & $\begin{array}{l}\text { Furlong and others, 2001; Glassmeyer and others, } \\
2005 .\end{array}$ \\
\hline SH2060/2033 & Carbofuran & $49309 / 82674$ & $1563-66-2$ & -- & Furlong and others, 2001; Zaugg and others, 1995. \\
\hline SH2003/2033 & Chlorpyrifos & 38933 & $2921-88-2$ & -- & $\begin{array}{l}\text { Zaugg and others, 1995; Glassmeyer and others, } \\
2005 .\end{array}$ \\
\hline SH2003/2033 & $\begin{array}{l}\text { Chlorpyrifos, oxygen } \\
\text { analog }\end{array}$ & 61636 & $5598-15-2$ & Insecticide (chlorpyrifos) degradate & Sandstrom and others, 2001. \\
\hline SH2003/2033 & cis-Permethrin & 82687 & $54774-45-7$ & -- & Zaugg and others, 1995. \\
\hline SH2003/2033 & Cyfluthrin & 61585 & $68359-37-5$ & -- & Sandstrom and others, 2001. \\
\hline SH2003/2033 & Cypermethrin & 61586 & $52315-07-8$ & -- & Sandstrom and others, 2001. \\
\hline SH2003/2033 & Desulfinylfipronil & 62170 & -- & Insecticide (fipronil) degradate & Madsen and others, 2003. \\
\hline SH2003/2033 & $\begin{array}{l}\text { Desulfinylfipronil } \\
\text { amide }\end{array}$ & 62169 & -- & Insecticide (fipronil) degradate & Madsen and others, 2003. \\
\hline SH2003/2033 & Diazinon & 39572 & $333-41-5$ & -- & $\begin{array}{l}\text { Zaugg and others, 1995; Sandstrom and others, } \\
\text { 2001; Glassmeyer and others, } 2005 .\end{array}$ \\
\hline SH2003/2033 & $\begin{array}{l}\text { Diazinon, oxygen } \\
\text { analog }\end{array}$ & 61638 & $962-58-3$ & Insecticide (diazinon) degradate & $\begin{array}{l}\text { Zaugg and others, 1995; Sandstrom and others, } \\
2001 .\end{array}$ \\
\hline SH2003/2033 & Dichlorvos & 38775 & $62-73-7$ & -- & $\begin{array}{l}\text { Zaugg and others, 1995; Sandstrom and others, } \\
\text { 2001; Glassmeyer and others, } 2005 .\end{array}$ \\
\hline SH2003/2033 & Dicrotophos & 38454 & $141-66-2$ & -- & $\begin{array}{l}\text { Zaugg and others, 1995; Sandstrom and others, } \\
2001 .\end{array}$ \\
\hline SH2003/2033 & Dieldrin & 39381 & $60-57-1$ & -- & $\begin{array}{l}\text { Zaugg and others, 1995; Sandstrom and others, } \\
2001 .\end{array}$ \\
\hline SH2003/2033 & Dimethoate & 82662 & $60-51-5$ & -- & $\begin{array}{l}\text { Zaugg and others, 1995; Sandstrom and others, } \\
2001 .\end{array}$ \\
\hline SH2033 & Disulfoton & 82677 & $298-04-4$ & -- & Zaugg and others, 1995. \\
\hline SH2033 & Disulfoton sulfone & 61640 & $2497-06-5$ & Insecticide (disulfoton) degradate & Sandstrom and others, 2001. \\
\hline SH2033 & Endosulfan sulfate & 61590 & $1031-07-8$ & Insecticide (alpha-endosulfan) degradate & Sandstrom and others, 2001. \\
\hline SH2003/2033 & Ethion & 82346 & $563-12-2$ & -- & Zaugg and others, 1995; Sandstrom and others, \\
\hline
\end{tabular}


Appendix 1. Compounds analyzed in Source Water-Quality Assessment studies by primary use or source groups.-Continued

[USGS, U.S. Geological Survey; CASRN, Chemical Abstracts Service Registry Number ${ }^{\circledR}$; --, no additional information]

\begin{tabular}{|c|c|c|c|c|c|}
\hline $\begin{array}{c}\text { USGS } \\
\text { analytical } \\
\text { schedule }\end{array}$ & $\begin{array}{c}\text { Compound name } \\
\text { (abbreviation or other } \\
\text { name) }\end{array}$ & $\begin{array}{c}\text { USGS } \\
\text { parameter } \\
\text { code }\end{array}$ & CASRN ${ }^{a}$ & Secondary uses or sources & References for use and source information \\
\hline \multicolumn{6}{|c|}{ Insecticides and insecticide degradates - Continued } \\
\hline SH2003/2033 & Ethion monoxon & 61644 & $17356-42-2$ & Insecticide (ethion) degradate & $\begin{array}{l}\text { Zaugg and others, 1995; Sandstrom and others, } \\
2001 .\end{array}$ \\
\hline SH2033 & Ethoprophos & 82672 & $13194-48-4$ & -- & Zaugg and others, 1995. \\
\hline SH2003/2033 & Fenamiphos & 61591 & $22224-92-6$ & -- & $\begin{array}{l}\text { Zaugg and others, 1995; Sandstrom and others, } \\
2001 .\end{array}$ \\
\hline SH2003/2033 & Fenamiphos sulfone & 61645 & $31972-44-8$ & Insecticide (fenamiphos) degradate & $\begin{array}{l}\text { Zaugg and others, 1995; Sandstrom and others, } \\
2001 .\end{array}$ \\
\hline SH2003/2033 & Fenamiphos sulfoxide & 61646 & $31972-43-7$ & Insecticide (fenamiphos) degradate & $\begin{array}{l}\text { Zaugg and others, 1995; Sandstrom and others, } \\
2001 .\end{array}$ \\
\hline SH2003/2033 & Fipronil & 62166 & $120068-37-3$ & -- & Madsen and others, 2003. \\
\hline SH2003/2033 & Fipronil sulfide & 62167 & $120067-83-6$ & Insecticide (fipronil) degradate & Madsen and others, 2003. \\
\hline SH2003/2033 & Fipronil sulfone & 62168 & $120068-36-2$ & Insecticide (fipronil) degradate & Madsen and others, 2003. \\
\hline SH2003/2033 & Fonofos & 04095 & $944-22-9$ & -- & Zaugg and others, 1995. \\
\hline SH2003 & $\begin{array}{l}\text { Fonofos, oxygen } \\
\text { analog }\end{array}$ & 61649 & $944-21-8$ & Insecticide (fonofos) degradate & Sandstrom and others, 2001. \\
\hline SH2060 & Imidacloprid & 61695 & $138261-41-3$ & -- & Furlong and others, 2001. \\
\hline SH2003/2033 & Isofenphos & 61594 & $25311-71-1$ & -- & Sandstrom and others, 2001. \\
\hline SH2033 & lambda-Cyhalothrin & 61595 & $91465-08-6$ & -- & Wood, 2010. \\
\hline SH2003/2033 & Malaoxon & 61652 & $1634-78-2$ & Insecticide (malathion) degradate & Sandstrom and others, 2001. \\
\hline SH2003/2033 & Malathion & 39532 & $121-75-5$ & -- & Zaugg and others, 1995. \\
\hline SH2003/2033 & Methidathion & 61598 & $950-37-8$ & -- & Sandstrom and others, 2001. \\
\hline SH2060 & Methiocarb & 38501 & $2032-65-7$ & -- & Furlong and others, 2001. \\
\hline SH2060 & Methomyl & 49296 & $16752-77-5$ & -- & Furlong and others, 2001. \\
\hline SH2060 & Oxamyl & 38866 & $23135-22-0$ & -- & Furlong and others, 2001. \\
\hline SH2003/2033 & Paraoxon-methyl & 61664 & $950-35-6$ & Insecticide (methyl parathion) degradate & Sandstrom and others, 2001. \\
\hline SH2003/2033 & Parathion-methyl & 82667 & $298-00-0$ & -- & Zaugg and others, 1995. \\
\hline SH2003/2033 & Phorate & 82664 & $298-02-2$ & -- & Zaugg and others, 1995. \\
\hline SH2003/2033 & Phorate oxon & 61666 & $2600-69-3$ & Insecticide (phorate) degradate & Sandstrom and others, 2001. \\
\hline SH2003/2033 & Phosmet & 61601 & $732-11-6$ & -- & Sandstrom and others, 2001. \\
\hline SH2003/2033 & Phosmet oxon & 61668 & $3735-33-9$ & Insecticide (phosmet) degradate & Sandstrom and others, 2001. \\
\hline SH2033 & Propargite & 82685 & $2312-35-8$ & -- & Zaugg and others, 1995. \\
\hline SH2060 & Propoxur & 38538 & $114-26-1$ & -- & Furlong and others, 2001. \\
\hline
\end{tabular}


Appendix 1. Compounds analyzed in Source Water-Quality Assessment studies by primary use or source groups.-Continued

[USGS, U.S. Geological Survey; CASRN, Chemical Abstracts Service Registry Number ${ }^{\mathbb{R}}$; --, no additional information]

\begin{tabular}{|c|c|c|c|c|c|}
\hline $\begin{array}{l}\text { USGS } \\
\text { analytical } \\
\text { schedule }\end{array}$ & $\begin{array}{c}\text { Compound name } \\
\text { (abbreviation or other } \\
\text { name) }\end{array}$ & $\begin{array}{l}\text { USGS } \\
\text { parameter } \\
\text { code }\end{array}$ & CASRN ${ }^{a}$ & Secondary uses or sources & References for use and source information \\
\hline \multicolumn{6}{|c|}{ Insecticides and insecticide degradates - Continued } \\
\hline SH2033 & Tefluthrin & 61606 & $79538-32-2$ & -- & Sandstrom and others, 2001. \\
\hline SH2003/2033 & Terbufos & 82675 & 13071-79-9 & -- & Zaugg and others, 1995. \\
\hline SH2003/2033 & $\begin{array}{l}\text { Terbufos oxygen ana- } \\
\text { logue sulfone }\end{array}$ & 61674 & $56070-15-6$ & Insecticide (terbufos) degradate & Sandstrom and others, 2001. \\
\hline \multicolumn{6}{|c|}{ Manufacturing additives } \\
\hline SH1433 & $\begin{array}{l}\text { 5-Methyl-1H-benzo- } \\
\text { triazole }\end{array}$ & 62063 & $136-85-6$ & $\begin{array}{l}\text { Corrosion inhibitor in de-icers/antifreeze, anti-fading } \\
\text { agent for metals, antiseptic and anticoagulant } \\
\text { agent, anti-fog for photography, ultraviolet-ab- } \\
\text { sorbers, photoconductor, copying systems, phar- } \\
\text { maceuticals, pesticide products and other specialty } \\
\text { chemicals, antioxidant }\end{array}$ & $\begin{array}{l}\text { Zaugg and others, 2002; Glassmeyer and others, } \\
\text { 2005; Chemicalland21, } 2010 .\end{array}$ \\
\hline SH1433 & Bisphenol A & 62069 & $80-05-7$ & $\begin{array}{l}\text { Used in manufacture of plastic and polycarbonate } \\
\text { resins }\end{array}$ & $\begin{array}{l}\text { Zaugg and others, 2002; Glassmeyer and others, } \\
\text { 2005; U.S. National Library of Medicine, } 2006 .\end{array}$ \\
\hline SH1433 & $\begin{array}{l}\text { Tri(2-butoxyethyl) } \\
\text { phosphate }\end{array}$ & 62093 & $78-51-3$ & Plasticizer, pesticide adjuvant, flame retardant & $\begin{array}{l}\text { Zaugg and others, 2002; Glassmeyer and others, } \\
\text { 2005; U.S. Environmental Protection Agency, } \\
\text { 2009. }\end{array}$ \\
\hline SH1433 & $\begin{array}{l}\text { Tri(2-chloroethyl) } \\
\text { phosphate }\end{array}$ & 62087 & $115-96-8$ & Flame retardant, fire resistant cellulose plasticizer & $\begin{array}{l}\text { Zaugg and others, 2002; Glassmeyer and others, } \\
2005 .\end{array}$ \\
\hline SH1433 & Tributyl phosphate & 62089 & $126-73-8$ & Antifoaming agent and flame retardant & Zaugg and others, 2002. \\
\hline SH1433 & Triphenyl phosphate & 62092 & $115-86-6$ & Plasticizer, flame retardant & $\begin{array}{l}\text { Budavari, 1989; Zaugg and others, 2002; Glassmey- } \\
\text { er and others, } 2005 .\end{array}$ \\
\hline SH1433 & $\begin{array}{l}\text { Tris(dichlorisopropyl) } \\
\text { phosphate }\end{array}$ & 62088 & $13674-87-8$ & Flame retardant, plasticizer & $\begin{array}{l}\text { Zaugg and others, 2002; Glassmeyer and others, } \\
\text { 2005; U.S. National Library of Medicine, } 2006 .\end{array}$ \\
\hline \multicolumn{6}{|c|}{ Organic synthesis compounds } \\
\hline SH2020 & 1,1-Dichloropropene & 77168 & $563-58-6$ & Solvent (pharmaceuticals) & Bender and others, 1999; Scorecard, 2006. \\
\hline SH2020 & $\begin{array}{l}\text { 1,2,3-Trichloroben- } \\
\text { zene }\end{array}$ & 77613 & $87-61-6$ & Termiticide, solvent & $\begin{array}{l}\text { Budavari, 1989, 1996; Bender and others, 1999; U.S. } \\
\text { National Library of Medicine, } 2006 .\end{array}$ \\
\hline SH2020 & 1,2,3-Trichloropropane & 77443 & $96-18-4$ & Fumigant contaminant, paint and varnish remover & $\begin{array}{l}\text { Agency for Toxic Substances and Disease Registry, } \\
\text { 1992a; Tesoriero and others, } 2001 .\end{array}$ \\
\hline SH2020 & 3-Chloro-1-propene & 78109 & $107-05-1$ & Fumigant contaminant & $\begin{array}{l}\text { Cohen and others, 1983; U.S. National Library of } \\
\text { Medicine, } 2006 .\end{array}$ \\
\hline SH2020 & Acrylonitrile & 34215 & $107-13-1$ & Fumigant, pesticide & Bender and others, 1999; Scorecard, 2006. \\
\hline
\end{tabular}


Appendix 1. Compounds analyzed in Source Water-Quality Assessment studies by primary use or source groups.-Continued

[USGS, U.S. Geological Survey; CASRN, Chemical Abstracts Service Registry Number ${ }^{\circledR}$; --, no additional information]

\begin{tabular}{|c|c|c|c|c|c|}
\hline $\begin{array}{l}\text { USGS } \\
\text { analytical } \\
\text { schedule }\end{array}$ & $\begin{array}{c}\text { Compound name } \\
\text { (abbreviation or other } \\
\text { name) }\end{array}$ & $\begin{array}{l}\text { USGS } \\
\text { parameter } \\
\text { code }\end{array}$ & CASRN $^{a}$ & Secondary uses or sources & References for use and source information \\
\hline \multicolumn{6}{|c|}{ Organic synthesis compounds-Continued } \\
\hline SH1433 & Anthraquinone & 62066 & $84-65-1$ & $\begin{array}{l}\text { Bird repellant, serves as the basis for the production } \\
\text { of a large number of acid and base dyes, vat dyes, } \\
\text { disperse dyes, and reactive dyes additive in the } \\
\text { soda and kraft chemical alkaline pulping process- } \\
\text { es in the paper pulping industry }\end{array}$ & $\begin{array}{l}\text { Zaugg and others, 2002; Glassmeyer and others, } \\
\text { 2005; Scorecard, 2006; U.S. National Library of } \\
\text { Medicine, } 2006 .\end{array}$ \\
\hline SH1433 & Carbazole & 62071 & $86-74-8$ & Synthesis of dyes, combustion product & $\begin{array}{l}\text { Budavari, 1989; Glassmeyer and others, 2005; U.S. } \\
\text { National Library of Medicine, } 2006 .\end{array}$ \\
\hline SH2020 & Carbon disulfide & 77041 & $75-15-0$ & $\begin{array}{l}\text { Solvent, syntheses, fumigant, sulfate-reduction } \\
\text { product }\end{array}$ & $\begin{array}{l}\text { Budavari, 1989; Megonigal and others, 2004; Score- } \\
\text { card, } 2006 .\end{array}$ \\
\hline SH2020 & Chloromethane & 34418 & $74-87-3$ & Blowing agent/propellant, solvent, refrigerant & $\begin{array}{l}\text { Budavari, 1989; U.S. National Library of Medicine, } \\
2006 .\end{array}$ \\
\hline SH2020 & $\begin{array}{l}\text { Ethyl methacrylate } \\
\text { (ethyl 2-methyl-2- } \\
\text { propanoate) }\end{array}$ & 73570 & $97-63-2$ & $\begin{array}{l}\text { Hairspray, used to make polymers, chemical inter- } \\
\text { mediate }\end{array}$ & $\begin{array}{l}\text { Scorecard, 2006; U.S. National Library of Medicine, } \\
2006 .\end{array}$ \\
\hline SH2020 & Hexachlorobutadiene & 39702 & $87-68-3$ & $\begin{array}{l}\text { Used in rubber manufacture, solvent, pesticide (non- } \\
\text { U.S.) }\end{array}$ & $\begin{array}{l}\text { Bender and others, 1999; California Environmental } \\
\text { Protection Agency, } 1999 .\end{array}$ \\
\hline SH2020 & Iodomethane & 77424 & $74-88-4$ & $\begin{array}{l}\text { Microscopy, circuit board manufacture, fire extin- } \\
\text { guishers, proposed fumigant }\end{array}$ & $\begin{array}{l}\text { Budavari, 1989; U.S. Environmental Protection } \\
\text { Agency, } 2006 .\end{array}$ \\
\hline SH2020 & $\begin{array}{l}\text { Methyl acrylate } \\
\text { (methyl-2- } \\
\text { propenoate) }\end{array}$ & 49991 & $96-33-3$ & Manufacture of resins, paper, plastic & $\begin{array}{l}\text { Budavari, 1989; U.S. National Library of Medicine, } \\
\text { 2006. }\end{array}$ \\
\hline SH2020 & $\begin{array}{l}\text { Methyl acrylonitrile } \\
\text { (2-methyl-2- } \\
\text { propenenitrile) }\end{array}$ & 81593 & $126-98-7$ & $\begin{array}{l}\text { Organic synthesis, polymer manufacture, chemical } \\
\text { intermediate }\end{array}$ & $\begin{array}{l}\text { Budavari, 1989; United Nations Environmental } \\
\text { Programme, 2002; U.S. National Library of Medi- } \\
\text { cine, } 2006 .\end{array}$ \\
\hline SH2020 & $\begin{array}{l}\text { Methyl methacrylate } \\
\text { (methyl 2-methyl-2- } \\
\text { propenoate) }\end{array}$ & 81597 & $80-62-6$ & $\begin{array}{l}\text { Manufacture of paint, paper, acrylic, chemical inter- } \\
\text { mediate, pesticide adjuvant }\end{array}$ & $\begin{array}{l}\text { U.S. National Library of Medicine, 2006; U.S. En- } \\
\text { vironmental Protection Agency, 2009; Spectrum } \\
\text { Laboratories Inc., 2010a. }\end{array}$ \\
\hline SH2020 & $\begin{array}{l}\text { trans-1,4-Dichloro-2- } \\
\quad \text { butene }\end{array}$ & 73547 & $110-57-6$ & Chemical intermediate & U.S. National Library of Medicine, 2006. \\
\hline SH2020 & Vinyl bromide & 50002 & $593-60-2$ & $\begin{array}{l}\text { Plastic manufacture, 1,2-dibromoethane degradate, } \\
\text { flame retardant }\end{array}$ & $\begin{array}{l}\text { Barbash and Reinhard, 1989; Bender and others, } \\
1999 .\end{array}$ \\
\hline SH2020 & Vinyl chloride & 39175 & $75-01-4$ & $\begin{array}{l}\text { Polyvinyl chloride (PVC) manufacture, refrigerant, } \\
\text { degradate of 1,2-dichloroethane (aerobic) and } \\
\text { dichloroethylene (anaerobic) }\end{array}$ & $\begin{array}{l}\text { Vogel and McCarty, 1985; Barbash and Reinhard, } \\
\text { 1989; Bender and others, } 1999 .\end{array}$ \\
\hline
\end{tabular}


Appendix 1. Compounds analyzed in Source Water-Quality Assessment studies by primary use or source groups.-Continued

[USGS, U.S. Geological Survey; CASRN, Chemical Abstracts Service Registry Number ${ }^{\mathbb{}}$; --, no additional information]

\begin{tabular}{|c|c|c|c|c|c|}
\hline $\begin{array}{l}\text { USGS } \\
\text { analytical } \\
\text { schedule }\end{array}$ & $\begin{array}{c}\text { Compound name } \\
\text { (abbreviation or other } \\
\text { name) }\end{array}$ & $\begin{array}{c}\text { USGS } \\
\text { parameter } \\
\text { code }\end{array}$ & CASRNa & Secondary uses or sources & References for use and source information \\
\hline \multicolumn{6}{|c|}{ Pavement- and combustion-derived compounds } \\
\hline SH1433 & Anthracene & 34221 & $120-12-7$ & $\begin{array}{l}\text { Polynuclear aromatic hydrocarbon, used in dye pro- } \\
\text { duction and production of plastic fibers, organic } \\
\text { synthesis (anthraquinone), wood preservative }\end{array}$ & Lee and Strahan, 2003; Glassmeyer and others, 2005. \\
\hline SH1433 & Benzo[a]pyrene & 34248 & $50-32-8$ & $\begin{array}{l}\text { Polynuclear aromatic hydrocarbon, cancer research } \\
\text { chemical }\end{array}$ & $\begin{array}{l}\text { Zaugg and others, 2002, Glassmeyer and others, } \\
2005 .\end{array}$ \\
\hline SH1433 & Fluoranthene & 34377 & $206-44-0$ & $\begin{array}{l}\text { Polynuclear aromatic hydrocarbon, used on inside } \\
\text { lining on iron water pipes and tanks, production of } \\
\text { fluorescent dyes and pharmaceuticals, component } \\
\text { of coal tar and asphalt }\end{array}$ & $\begin{array}{l}\text { Glassmeyer and others, 2005; U.S. National Library } \\
\text { of Medicine, } 2006 .\end{array}$ \\
\hline SH1433 & Phenanthrene & 34462 & $85-01-8$ & $\begin{array}{l}\text { Polynuclear aromatic hydrocarbon, manufacture of } \\
\text { dyes, explosives, and drugs, used in research }\end{array}$ & $\begin{array}{l}\text { Zaugg and others, 2002; Glassmeyer and others, } \\
2005 .\end{array}$ \\
\hline SH1433 & Pyrene & 34470 & $129-00-0$ & $\begin{array}{l}\text { Polynuclear aromatic hydrocarbon, used to synthe- } \\
\text { size benzo[a]pyrene, used as a starting material } \\
\text { in the production of optical brighteners and dyes, } \\
\text { research chemical, component of coal tar and } \\
\text { asphalt }\end{array}$ & $\begin{array}{l}\text { Glassmeyer and others, 2005; U.S. National Library } \\
\text { of Medicine, } 2006 .\end{array}$ \\
\hline \multicolumn{6}{|c|}{ Personal-care and domestic-use products } \\
\hline SH1433 & $\begin{array}{l}\text { 3-tert-Butyl-4-hydroxy } \\
\text { anisole (BHA) }\end{array}$ & 62059 & $25013-16-5$ & $\begin{array}{l}\text { Antioxidant, preservative, food packaging, and rub- } \\
\text { ber and petroleum products }\end{array}$ & $\begin{array}{l}\text { Zaugg and others, 2002; Glassmeyer and others, } \\
2005 .\end{array}$ \\
\hline SH1433 & 4-Cumylphenol & 62060 & $599-64-4$ & Nonionic detergent metabolite & $\begin{array}{l}\text { Zaugg and others, 2002; Glassmeyer and others, } \\
2005 .\end{array}$ \\
\hline SH1433 & 4- $n$-Octylphenol & 62061 & $1806-26-4$ & Nonionic detergent metabolite & $\begin{array}{l}\text { Zaugg and others, 2002; Glassmeyer and others, } \\
2005 .\end{array}$ \\
\hline SH1433 & 4-tert-Octylphenol & 62062 & $140-66-9$ & Nonionic detergent metabolite & $\begin{array}{l}\text { Zaugg and others, 2002; Glassmeyer and others, } \\
2005 .\end{array}$ \\
\hline SH1433 & Acetophenone & 62064 & $98-86-2$ & $\begin{array}{l}\text { Fragrance, flavorant, solvent for paint and varnish } \\
\text { removal, plastics and resins }\end{array}$ & $\begin{array}{l}\text { Zaugg and others, 2002; Glassmeyer and others, } \\
\text { 2005; Scorecard, 2006; U.S. National Library of } \\
\text { Medicine, } 2006 .\end{array}$ \\
\hline SH1433 & $\begin{array}{l}\text { Acetyl hexamethyl tet- } \\
\text { rahydronaphthalene } \\
\text { (AHTN) }\end{array}$ & 62065 & $21145-77-7$ & Widely used musk fragrance & Zaugg and others, 2002. \\
\hline SH1433 & Benzophenone & 62067 & $119-61-9$ & $\begin{array}{l}\text { Fixative in perfumes and soaps, hair mousse, inks, } \\
\text { organic synthesis }\end{array}$ & $\begin{array}{l}\text { Zaugg and others, 2002; Glassmeyer and others, } \\
\text { 2005; Scorecard, 2006; U.S. National Library of } \\
\text { Medicine, } 2006 .\end{array}$ \\
\hline SH2020 & Bromochloromethane & 77297 & $74-97-5$ & $\begin{array}{l}\text { Fire extinguishing fluid, intermediate in pesticide } \\
\text { manufacturing }\end{array}$ & $\begin{array}{l}\text { Bender and others, 1999; U.S. National Library of } \\
\text { Medicine, } 2006 .\end{array}$ \\
\hline SH2060 & Caffeine & 50305 & $58-08-2$ & Beverage ingredient, diuretic & $\begin{array}{l}\text { Furlong and others, 2001; Glassmeyer and others, } \\
2005 .\end{array}$ \\
\hline
\end{tabular}


Appendix 1. Compounds analyzed in Source Water-Quality Assessment studies by primary use or source groups.-Continued

[USGS, U.S. Geological Survey; CASRN, Chemical Abstracts Service Registry Number ${ }^{\mathbb{}}$; --, no additional information]

\begin{tabular}{|c|c|c|c|c|c|}
\hline $\begin{array}{c}\text { USGS } \\
\text { analytical } \\
\text { schedule }\end{array}$ & $\begin{array}{l}\text { Compound name } \\
\text { (abbreviation or other } \\
\text { name) }\end{array}$ & $\begin{array}{l}\text { USGS } \\
\text { parameter } \\
\text { code }\end{array}$ & CASRNa & Secondary uses or sources & References for use and source information \\
\hline \multicolumn{6}{|c|}{ Personal-care and domestic-use products-Continued } \\
\hline SH1433 & Camphor & 62070 & $76-22-2$ & $\begin{array}{l}\text { Flavorant and odorant, used in manufacture of } \\
\text { plastics, as plasticizer for cellulose esters and } \\
\text { ethers, in lacquers and varnishes, in explosives, in } \\
\text { pyrotechnics, in embalming fluid, in manufacture } \\
\text { of cymene, in camphorated parachlorophenol, } \\
\text { paregoric, and flexible collodion }\end{array}$ & $\begin{array}{l}\text { Budavari, 1989; Zaugg and others, 2002; U.S. Na- } \\
\text { tional Library of Medicine, 2010; Glassmeyer and } \\
\text { others, } 2005 .\end{array}$ \\
\hline SH1433 & Cotinine & 62005 & $486-56-6$ & Primary nicotine metabolite, nonprescription drug & $\begin{array}{l}\text { Kolpin and others, 2002; Zaugg and others, 2002; } \\
\text { Glassmeyer and others, } 2005 .\end{array}$ \\
\hline SH1433 & $d$-Limonene & 62073 & $5989-27-5$ & Antimicrobial, fragrance & $\begin{array}{l}\text { Zaugg and others, 2002; Glassmeyer and others, } \\
2005 \text {. }\end{array}$ \\
\hline SH1433 & $\begin{array}{l}\text { Hexahydrohexamethyl- } \\
\text { cyclopentabenzo- } \\
\text { pyran (HHCB) }\end{array}$ & 62075 & $1222-05-5$ & Widely used musk fragrance & $\begin{array}{l}\text { Zaugg and others, 2002; Glassmeyer and others, } \\
2005 .\end{array}$ \\
\hline SH1433 & Indole & 62076 & $120-72-9$ & Pesticide adjuvant, coffee ingredient, fragrance & $\begin{array}{l}\text { Zaugg and others, 2002; Glassmeyer and others, } \\
\text { 2005; Scorecard, 2006; U.S. Environmental Pro- } \\
\text { tection Agency, 2009. }\end{array}$ \\
\hline SH1433 & Isoborneol & 62077 & $124-76-5$ & Flavorant, fragrance, disinfection ingredient & $\begin{array}{l}\text { Zaugg and others, 2002; Glassmeyer and others, } \\
\text { 2005; Scorecard, 2006; U.S. National Library of } \\
\text { Medicine, } 2006 .\end{array}$ \\
\hline SH1433 & Isoquinoline & 62079 & $119-65-3$ & Flavors and fragrances & $\begin{array}{l}\text { Zaugg and others, 2002; Glassmeyer and others, } \\
2005 \text {. }\end{array}$ \\
\hline SH1433 & $\begin{array}{l}\text { Menthol (5-methyl- } \\
\text { 2-[1-methylethyl] } \\
\text { cyclohexanol) }\end{array}$ & 62080 & $89-78-1$ & Cigarettes, cough drops, liniment, mouthwash & Zaugg and others, 2002. \\
\hline SH1433 & Methyl salicylate & 62081 & $119-36-8$ & Analgesic, decongestant, toilet and window cleaner & $\begin{array}{l}\text { Kolpin and others, 2002; Zaugg and others, 2002; } \\
\text { Glassmeyer and others, 2005; Scorecard, } 2006 .\end{array}$ \\
\hline SH1433 & $\begin{array}{l}\text { N,N-diethyl-meta- } \\
\text { toluamide (DEET) }\end{array}$ & 62082 & $134-62-3$ & Insect repellent & $\begin{array}{l}\text { Zaugg and others, 2002; Glassmeyer and others, } \\
2005 .\end{array}$ \\
\hline SH1433 & $\begin{array}{l}\text { Nonylphenol, } \\
\text { diethoxy- (total) }\end{array}$ & 62083 & $26027-38-2$ & Nonionic detergent metabolite & Zaugg and others, 2002. \\
\hline SH1433 & $\begin{array}{l}\text { Octylphenol, diethoxy- } \\
\text { (OPEO2) }\end{array}$ & 61705 & -- & Nonionic detergent metabolite & Zaugg and others, 2002. \\
\hline SH1433 & $\begin{array}{l}\text { Octylphenol, mono- } \\
\text { ethoxy- (OPEO1) }\end{array}$ & 61706 & -- & Nonionic detergent metabolite & Zaugg and others, 2002. \\
\hline SH1433 & $\begin{array}{l}\text { para-Nonylphenol } \\
\quad \text { (total) }\end{array}$ & 62085 & $84852-15-3$ & Surfactant intermediate & $\begin{array}{l}\text { Zaugg and others, 2002; Glassmeyer and others, } \\
2005 .\end{array}$ \\
\hline
\end{tabular}


Appendix 1. Compounds analyzed in Source Water-Quality Assessment studies by primary use or source groups.-Continued

[USGS, U.S. Geological Survey; CASRN, Chemical Abstracts Service Registry Number ${ }^{\mathbb{R}}$; --, no additional information]

\begin{tabular}{|c|c|c|c|c|c|}
\hline $\begin{array}{l}\text { USGS } \\
\text { analytical } \\
\text { schedule }\end{array}$ & $\begin{array}{l}\text { Compound name } \\
\text { (abbreviation or other } \\
\text { name) }\end{array}$ & $\begin{array}{l}\text { USGS } \\
\text { parameter } \\
\text { code }\end{array}$ & CASRN $^{a}$ & Secondary uses or sources & References for use and source information \\
\hline \multicolumn{6}{|c|}{ Personal-care and domestic-use products-Continued } \\
\hline SH1433 & Phenol & 34466 & $108-95-2$ & Disinfectant & $\begin{array}{l}\text { Zaugg and others, 2002; Glassmeyer and others, } \\
2005 .\end{array}$ \\
\hline SH1433 & Triclosan & 62090 & $3380-34-5$ & $\begin{array}{l}\text { Antimicrobial, preservative for cosmetics and deter- } \\
\text { gents preparations }\end{array}$ & $\begin{array}{l}\text { Zaugg and others, 2002; Glassmeyer and others, } \\
2005 .\end{array}$ \\
\hline SH1433 & Triethyl citrate & 62091 & $77-93-0$ & Cosmetics, pharmaceuticals, plasticizer & $\begin{array}{l}\text { Zaugg and others, 2002; Glassmeyer and others, } \\
\text { 2005; U.S. National Library of Medicine, } 2006 .\end{array}$ \\
\hline \multicolumn{6}{|c|}{ Plant- or animal-derived biochemicals } \\
\hline SH1433 & 3-beta-Coprostanol & 62057 & $360-68-9$ & Fecal indicator (carnivores) & $\begin{array}{l}\text { Zaugg and others, 2002; Glassmeyer and others, } \\
2005 .\end{array}$ \\
\hline SH1433 & $\begin{array}{l}\text { 3-Methyl-1(H)-indole } \\
\text { (Skatole) }\end{array}$ & 62058 & $83-34-1$ & In animal waste, stench in feces, in coal tar & $\begin{array}{l}\text { Zaugg and others, 2002; Glassmeyer and others, } \\
2005 .\end{array}$ \\
\hline SH1433 & beta-Sitosterol & 62068 & $83-46-5$ & Plant sterol & $\begin{array}{l}\text { Zaugg and others, 2002; Glassmeyer and others, } \\
2005 .\end{array}$ \\
\hline SH1433 & beta-Stigmastanol & 62086 & $19466-47-8$ & Plant sterol & $\begin{array}{l}\text { Zaugg and others, 2002; Glassmeyer and others, } \\
2005 .\end{array}$ \\
\hline SH1433 & Cholesterol & 62072 & $57-88-5$ & Fecal indicator, plant sterol & $\begin{array}{l}\text { Zaugg and others, 2002; Glassmeyer and others, } \\
2005 .\end{array}$ \\
\hline \multicolumn{6}{|c|}{ Refrigerants and propellants } \\
\hline SH2020 & $\begin{array}{l}\text { 1,1,2-Trichloro-1,2,2- } \\
\text { trifluoroethane } \\
\quad(\mathrm{CFC}-113)\end{array}$ & 77652 & $76-13-1$ & $\begin{array}{l}\text { Electroplating, degreasing, adhesives, textiles, pesti- } \\
\text { cide adjuvant }\end{array}$ & $\begin{array}{l}\text { Bender and others, 1999; CambridgeSoft Corpora- } \\
\text { tion, 2010; Scorecard, 2006; U.S. Environmental } \\
\text { Protection Agency, } 2009 .\end{array}$ \\
\hline SH2020 & $\begin{array}{l}\text { Dichlorodifluorometh- } \\
\text { ane (CFC-12) }\end{array}$ & 34668 & $75-71-8$ & Insulation, inhalers, insecticide, pesticide adjuvant & $\begin{array}{l}\text { Bender and others, 1999; CambridgeSoft Corpora- } \\
\text { tion, 2010; Scorecard, 2006; U.S. Environmental } \\
\text { Protection Agency, } 2009 .\end{array}$ \\
\hline SH2020 & $\begin{array}{l}\text { Trichlorofluorometh- } \\
\text { ane (CFC-11) }\end{array}$ & 34488 & $75-69-4$ & Hairspray, inhalers, insecticide, pesticide adjuvant & $\begin{array}{l}\text { Bender and others, 1999; CambridgeSoft Corpora- } \\
\text { tion, 2010; Scorecard, 2006; U.S. Environmental } \\
\text { Protection Agency, } 2009 .\end{array}$ \\
\hline \multicolumn{6}{|c|}{ Solvents } \\
\hline SH2020 & $\begin{array}{l}\text { 1,1,1,2-Tetrachloro- } \\
\text { ethane }\end{array}$ & 77562 & $630-20-6$ & Solvent for varnish & Bender and others, 1999; Scorecard, 2006. \\
\hline SH2020 & 1,1,1-Trichloroethane & 34506 & $71-55-6$ & $\begin{array}{l}\text { Electronics, pharmaceutical manufacture, degreaser; } \\
\text { pesticide adjuvant, fumigant }\end{array}$ & $\begin{array}{l}\text { Bender and others, 1999; Scorecard, 2006; U.S. } \\
\text { Environmental Protection Agency, } 2009 .\end{array}$ \\
\hline SH2020 & $\begin{array}{l}\text { 1,1,2,2-Tetrachloro- } \\
\text { ethane }\end{array}$ & 34516 & $79-34-5$ & $\begin{array}{l}\text { Manufacture of solvents, insecticide, pesticide } \\
\text { adjuvant }\end{array}$ & $\begin{array}{l}\text { Bender and others, 1999; Scorecard, 2006; U.S. } \\
\text { Environmental Protection Agency, } 2009 .\end{array}$ \\
\hline SH2020 & 1,1,2-Trichloroethane & 34511 & $79-00-5$ & Aerosol paints, manufacture solvent & Bender and others, 1999; Scorecard, 2006. \\
\hline
\end{tabular}


Appendix 1. Compounds analyzed in Source Water-Quality Assessment studies by primary use or source groups.-Continued

[USGS, U.S. Geological Survey; CASRN, Chemical Abstracts Service Registry Number ${ }^{\circledR}$; --, no additional information]

\begin{tabular}{|c|c|c|c|c|c|}
\hline $\begin{array}{l}\text { USGS } \\
\text { analytical } \\
\text { schedule }\end{array}$ & $\begin{array}{c}\text { Compound name } \\
\text { (abbreviation or other } \\
\text { name) }\end{array}$ & $\begin{array}{c}\text { USGS } \\
\text { parameter } \\
\text { code }\end{array}$ & CASRNa & Secondary uses or sources & References for use and source information \\
\hline \multicolumn{6}{|c|}{ Solvents-Continued } \\
\hline SH2020 & 1,1-Dichloroethane & 34496 & $75-34-3$ & $\begin{array}{l}\text { Lubricant, cleaner; anaerobic 1,1,1-trichloroethane } \\
\text { degradate }\end{array}$ & $\begin{array}{l}\text { Klecka and others, 1990; Bender and others, 1999; } \\
\text { Scorecard, } 2006 .\end{array}$ \\
\hline SH2020 & 1,1-Dichloroethene & 34501 & $75-35-4$ & $\begin{array}{l}\text { 1,1,1-trichloroethane degradate (aerobic); } \\
\text { pharmaceutical solvent }\end{array}$ & $\begin{array}{l}\text { Haag and Mill, 1988; Bender and others, 1999; } \\
\text { Scorecard, } 2006 .\end{array}$ \\
\hline SH2020 & $\begin{array}{l}\text { 1,2,4-Trichloroben- } \\
\text { zene }\end{array}$ & 34551 & $120-82-1$ & Manufacture of solvents; insecticide & Bender and others, 1999; Scorecard, 2006. \\
\hline SH2020 & $\begin{array}{l}\text { 1,2-Dichlorobenzene } \\
\text { (o-dichlorobenzene) }\end{array}$ & 34536 & $95-50-1$ & Disinfectant, deodorant, consumer solvent & Bender and others, 1999; Scorecard, 2006. \\
\hline SH2020 & $\begin{array}{l}\text { 1,2-Dichloroethane } \\
\text { (ethylene dichlo- } \\
\text { ride) }\end{array}$ & 32103 & $107-06-2$ & $\begin{array}{l}\text { Fumigant, manufacture of solvents, anti-knock com- } \\
\text { pound in gasoline }\end{array}$ & $\begin{array}{l}\text { Bender and others, 1999; National Oceanic and At- } \\
\text { mospheric Administration, 2008; Scorecard, } 2006 .\end{array}$ \\
\hline SH2020 & $\begin{array}{l}\text { 1,3-Dichlorobenzene } \\
\quad \text { (m-dichloroben- } \\
\text { zene) }\end{array}$ & 34566 & $541-73-1$ & Organic synthesis, fumigant & Bender and others, 1999. \\
\hline SH2020 & 2-Chlorotoluene & 77275 & $95-49-8$ & Pesticide adjuvant & $\begin{array}{l}\text { Bender and others, 1999; U.S. Environmental Pro- } \\
\text { tection Agency, } 2009 .\end{array}$ \\
\hline SH2020 & 2-Hexanone & 77103 & $591-78-6$ & Organic synthesis & $\begin{array}{l}\text { Agency for Toxic Substances and Disease Registry, } \\
\text { 1992b; Spectrum Laboratories Inc., 2010b. }\end{array}$ \\
\hline SH2020 & 4-Chlorotoluene & 77277 & $106-43-4$ & Pesticide adjuvant & $\begin{array}{l}\text { Bender and others, 1999; U.S. Environmental Pro- } \\
\text { tection Agency, } 2009 .\end{array}$ \\
\hline SH2020 & Acetone (2-propanone) & 81552 & $67-64-1$ & $\begin{array}{l}\text { Organic synthesis, chemical intermediate, pesticide } \\
\text { adjuvant }\end{array}$ & $\begin{array}{l}\text { Budavari, 1989; U.S. Environmental Protection } \\
\text { Agency, } 2009 .\end{array}$ \\
\hline SH2020 & Bromobenzene & 81555 & $108-86-1$ & Organic synthesis, additive to oil & $\begin{array}{l}\text { Bender and others, 1999; U.S. National Library of } \\
\text { Medicine, } 2006 .\end{array}$ \\
\hline SH2020 & Carbon tetrachloride & 32102 & $56-23-5$ & Fumigant, solvent & Bender and others, 1999; Scorecard, 2006. \\
\hline SH2020 & Chlorobenzene & 34301 & $108-90-7$ & Disinfectant, herbicide, building materials, solvent & $\begin{array}{l}\text { Budavari, 1989; Bender and others, 1999; Scorecard, } \\
\quad 2006 .\end{array}$ \\
\hline SH2020 & Chloroethane & 34311 & $75-00-3$ & $\begin{array}{l}\text { Refrigerant, anaerobic degradation of 1,1,1-trichlo- } \\
\text { roethane and 1,1-dichloroethane, manufacture of } \\
\text { tetraethyl lead }\end{array}$ & $\begin{array}{l}\text { Klecka and others, 1990; Bender and others, 1999; } \\
\text { Lorah and Olsen, } 1999 .\end{array}$ \\
\hline SH2020 & cis-1,2-Dichloroethene & 77093 & $156-59-2$ & Trichloroethene degradate (anaerobic) & Bender and others, 1999; Lorah and Olsen, 1999. \\
\hline SH2020 & Dibromomethane & 30217 & $74-95-3$ & $\begin{array}{l}\text { Organic synthesis (pesticide manufacture), heavy } \\
\text { liquid for mineral separations, fire extinguishers }\end{array}$ & Bender and others, 1999. \\
\hline SH2020 & $\begin{array}{l}\text { Diethyl ether } \\
\quad(1,1 \text { '-oxybisethane })\end{array}$ & 81576 & $60-29-7$ & Detergent, solvent, pharmaceuticals, cosmetics & Budavari, 1989; Scorecard, 2006. \\
\hline
\end{tabular}


Appendix 1. Compounds analyzed in Source Water-Quality Assessment studies by primary use or source groups.-Continued

[USGS, U.S. Geological Survey; CASRN, Chemical Abstracts Service Registry Number ${ }^{\mathbb{R}}$; --, no additional information]

\begin{tabular}{|c|c|c|c|c|c|}
\hline $\begin{array}{l}\text { USGS } \\
\text { analytical } \\
\text { schedule }\end{array}$ & $\begin{array}{c}\text { Compound name } \\
\text { (abbreviation or other } \\
\text { name) }\end{array}$ & $\begin{array}{l}\text { USGS } \\
\text { parameter } \\
\text { code }\end{array}$ & CASRNa & Secondary uses or sources & References for use and source information \\
\hline \multicolumn{6}{|c|}{ Solvents-Continued } \\
\hline SH2020 & Hexachloroethane & 34396 & $67-72-1$ & Lubricant, dry cleaning solvent & Budavari, 1989; Scorecard, 2006. \\
\hline SH1433 & Isophorone & 34409 & $78-59-1$ & Herbicide, adjuvant, solvent & $\begin{array}{l}\text { Zaugg and others, 2002; Glassmeyer and others, } \\
\text { 2005; Scorecard, 2006; U.S. Environmental } \\
\text { Protection Agency, 2009; U.S. National Library of } \\
\text { Medicine, } 2006 .\end{array}$ \\
\hline SH4024 & Methyl acetate & 77032 & $79-20-9$ & Aerosol paints & Scorecard, 2006. \\
\hline SH2020 & $\begin{array}{l}\text { Methyl ethyl ketone } \\
\text { (MEK) }\end{array}$ & 81595 & $78-93-3$ & $\begin{array}{l}\text { Adjuvant, solvent, cleaners, polyvinyl chloride } \\
\text { (PVC) glue and primer }\end{array}$ & $\begin{array}{l}\text { Bender and others, 1999; Scorecard, 2006; U.S. } \\
\text { Environmental Protection Agency, } 2009 .\end{array}$ \\
\hline SH2020 & $\begin{array}{l}\text { Methyl isobutyl ketone } \\
\text { (MIBK) (4-methyl- } \\
\text { 2-pentanone) }\end{array}$ & 78133 & $108-10-1$ & $\begin{array}{l}\text { Solvent, personal care products, insecticide, pesti- } \\
\text { cide adjuvant, polyvinyl chloride (PVC) glue }\end{array}$ & $\begin{array}{l}\text { Budavari, 1989; Scorecard, 2006; U.S. Environmen- } \\
\text { tal Protection Agency, } 2009 .\end{array}$ \\
\hline SH2020 & Methylene chloride & 34423 & $75-09-2$ & $\begin{array}{l}\text { Solvent, personal care products, insecticide, rodenti- } \\
\text { cide, fumigant, dog repellent, anaerobic degrada- } \\
\text { tion of carbon tetrachloride, polyvinyl chloride } \\
\text { (PVC) glue substitute }\end{array}$ & $\begin{array}{l}\text { Egli and others, 1988; Bender and others, 1999; } \\
\text { Scorecard, } 2006 .\end{array}$ \\
\hline SH2020 & $n$-Propylbenzene & 77224 & $103-65-1$ & Insulation, flooring manufacture & Bender and others, 1999; Scorecard, 2006. \\
\hline SH1433 & $p$-Cresol & 62084 & $106-44-5$ & $\begin{array}{l}\text { Paint/varnish removal, solvent, disinfectant, chemi- } \\
\text { cal intermediate for synthetic resins }\end{array}$ & $\begin{array}{l}\text { Budavari, 1989; Zaugg and others, 2002; Glassmey- } \\
\text { er and others, 2005; Scorecard, } 2006 .\end{array}$ \\
\hline SH2020 & $\begin{array}{l}\text { Perchloroethene (PCE; } \\
\text { tetrachloroethene) }\end{array}$ & 34475 & $127-18-4$ & Fumigant, solvent & $\begin{array}{l}\text { Bender and others, 1999; Glassmeyer and others, } \\
\text { 2005; Scorecard, } 2006 .\end{array}$ \\
\hline SH2020 & $\begin{array}{l}\text { Tetrahydrofuran } \\
\quad(1,4 \text {-epoxybutane })\end{array}$ & 81607 & 109-99-9 & $\begin{array}{l}\text { Adjuvant, cleaners, solvent, polyvinyl chloride } \\
\text { (PVC) glue and primer }\end{array}$ & $\begin{array}{l}\text { Budavari, 1989; Scorecard, 2006; U.S. Environmen- } \\
\text { tal Protection Agency, } 2009 .\end{array}$ \\
\hline SH2020 & $\begin{array}{l}\text { trans-1,2-Dichloro- } \\
\quad \text { ethene }\end{array}$ & 34546 & $156-60-5$ & Trichloroethene degradate & Bender and others, 1999; Lorah and Olsen, 1999. \\
\hline SH2020 & Trichloroethene (TCE) & 39180 & $79-01-6$ & $\begin{array}{l}\text { Fumigant, solvent, anaerobic perchloroethene } \\
\text { degradate }\end{array}$ & $\begin{array}{l}\text { Vogel and McCarty, 1985; Bender and others, 1999; } \\
\text { Scorecard, } 2006 .\end{array}$ \\
\hline
\end{tabular}

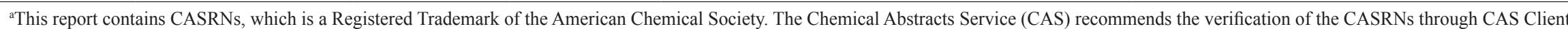
Services ${ }^{\mathrm{SM}}$.

${ }^{\text {b}}$ Letter prefix added to CASRN because CASRN not available for cis- or trans-isomers. 



\section{Appendix 2. Concentrations of anthropogenic organic compounds in groundwater and associated finished water from community water systems and in quality-assurance samples for Source Water-Quality Assessment studies, 2002-10}


The Microsoft Excel spreadsheet ( $g$ wdata.xls) contains a worksheet (worksheet: Documentation and abbreviations) that describes the documentation and abbreviations used in Appendix 2. The spreadsheet also contains concentration data and quality-assurance/quality-control data for each use (or source) group in separate worksheets named as follows:

1. Disinfection by-products (worksheet: Disinfection by-products)

2. Fumigant-related compounds (worksheet: Fumigant-related compounds)

3. Fungicides and fungicide degradates (worksheet: Fungicides)

4. Gasoline hydrocarbons, oxygenates, and oxygenate degradates (worksheet: Gasoline hydrocarbons)

5. Herbicides and herbicide degradates (worksheet: Herbicides)

6. Insecticides and insecticide degradates (worksheet: Insecticides)

7. Manufacturing additives (worksheet: Manufacturing additives)

8. Organic synthesis compounds (worksheet: Organic synthesis compounds)

9. Pavement- and combustion-derived compounds (worksheet: Pavement- \& combustion-derived)

10. Personal-care and domestic-use products (worksheet: Personal-care products)

11. Plant- or animal-derived biochemicals (worksheet: Plant- or animal-derived biochem)

12. Refrigerants and propellants (worksheet: Refrigerants and propellants)

13. Solvents (worksheet: Solvents)

A tab-delimited text file (Appendix2_readme.txt) describes the documentation and abbreviations used in Appendix 2. A tab-delimited text file for concentration data is presented for each use (or source) group as follows:

1. Disinfection by-products (gw_byprod.txt)

2. Fumigant-related compounds ( $g$ w fumigant.txt)

3. Fungicides and fungicide degradates ( $g w$ fungicide.txt)

4. Gasoline hydrocarbons, oxygenates, and oxygenate degradates ( $g$ w_gashydrocarb.txt)

5. Herbicides and herbicide degradates (gw_herbicide.txt)

6. Insecticides and insecticide degradates ( $g$ w_insecticide.txt)

7. Manufacturing additives ( $g$ w_manufact.txt)

8. Organic synthesis compounds ( $g$ w_orgsyn.txt)

9. Pavement- and combustion-derived compounds ( $g w$ pavement.txt)

10. Personal-care and domestic-use products ( $g w \_$personal.txt)

11. Plant- or animal-derived biochemicals (gw_biochem.txt)

12. Refrigerants and propellants (gw_refrig.txt)

13. Solvents (gw_solvent.txt) 


\begin{abstract}
Appendix 3. Concentrations of anthropogenic organic compounds in surface water and associated finished water from community water systems and in quality-assurance samples for Source Water-Quality Assessment studies, 2002-10
\end{abstract}


The Microsoft Excel spreadsheet (swdata.xls) contains a worksheet (worksheet: Documentation and abbreviations) that describes the documentation and abbreviations used in Appendix 3. The spreadsheet also contains concentration and quality-assurance/quality-control data for surface water and the associated finished water for each use (or source) group in separate worksheets named as follows:

1. Disinfection by-products (worksheet: Disinfection by-products)

2. Fumigant-related compounds (worksheet: Fumigant-related compounds)

3. Fungicides and fungicide degradates (worksheet: Fungicides)

4. Gasoline hydrocarbons, oxygenates, and oxygenate degradates (worksheet: Gasoline hydrocarbons)

5. Herbicides and herbicide degradates (worksheet: Herbicides)

6. Insecticides and insecticide degradates (worksheet: Insecticides)

7. Manufacturing additives (worksheet: Manufacturing additives)

8. Organic synthesis compounds (worksheet: Organic synthesis compounds)

9. Pavement- and combustion-derived compounds (worksheet: Pavement- \& combustion-derived)

10. Personal-care and domestic-use products (worksheet: Personal-care products)

11. Plant- or animal-derived biochemicals (worksheet: Plant- or animal-derived bioche)

12. Refrigerants and propellants (worksheet: Refrigerants and propellants)

13. Solvents (worksheet: Solvents)

A tab-delimited text file (Appendix__readme.txt) describes the documentation and abbreviations used in Appendix 3. A tab-delimited text file for concentration data is presented for each use (or source) group as follows:

1. Disinfection by-products (sw_byprod.txt)

2. Fumigant-related compounds (sw_fumigant.txt)

3. Fungicides and fungicide degradates (sw_fungicide.txt)

4. Gasoline hydrocarbons, oxygenates, and oxygenate degradates (sw_gashydrocarb.txt)

5. Herbicides and herbicide degradates (sw_herbicide.txt)

6. Insecticides and insecticide degradates (sw_insecticide.txt)

7. Manufacturing additives (sw_manufact.txt)

8. Organic synthesis compounds (sw_orgsyn.txt)

9. Pavement- and combustion-derived compounds ( $s w \_$pavement.txt)

10. Personal-care and domestic-use products ( $s w \_$personal.txt)

11. Plant- or animal-derived biochemicals (sw_biochem.txt)

12. Refrigerants and propellants (sw_refrig.txt)

13. Solvents (sw_solvent.txt) 
Publishing support provided by:

Rolla Publishing Service Center

For more information concerning this publication, contact:

Director, USGS South Dakota Water Science Center

1608 Mountain View Road, Rapid City, SD 57702

(605) 394-3200

http://sd.water.usgs.gov/

Information regarding the National Water-Quality Assessment Program is available at: http://water.usgs.gov/nawqa/ 

